Araştırma Makalesi - Research Article

\title{
Sosyal İnovasyon ve Artımsal İnovasyon Çerçevesinde İç-Göç Olgusunun Dinamik Mekânsal Etkileşimi
}

\section{Dynamic Spatial Interaction of Internal Migration on the Social Innovation and Incremental Innovation Framework}

\author{
M. Kenan TERZİĞLU* \\ (iD) 0000-0002-6053-830X \\ Mehmet Ali YÜCEL** \\ (iD) 0000-0002-5474-3307 \\ Ayhan GENÇLER*** \\ (iD) 0000-0002-5946-207X \\ ÖZ
}

Ülke sınırları içerisindeki toplumsal, sosyo-kültürel, iktisadi ve siyasal nedenlerden ötürü bireysel/kolektif yer değişimi olarak tanımlanan iç-göç hareketliliği, kentsel/bölgesel sorunsallıklar oluşturarak ulusal sürdürülebilirliği sekteye uğratmaktadır. Düzensiz ve denetimsiz gerçekleşen göç hareketliliği, nüfus dağılımının homojen yapı sergilememesine neden olarak, kentlerin yaşanabilir olma özelliklerini kaybetmelerine ve farklı kentsel sorunsallıkların (trafik, istihdam, kültürel erişilebilirlik vb. gibi) oluşmasına neden olmaktadır. Kentsel sorunsallıklar, kentsel/ulusal düzeyde inovasyon faaliyetlerinin artırılmasıyla engellenmektedir. Makale kapsamında, 2011-2018 yılları baz alınarak sosyal inovasyon göstergesi olarak ele alınan kentlerdeki sosyal hizmet alan kişi sayısının ve artımsal inovasyon göstergeleri olarak ele alınan kentlerin ihracat, girişimcilik ve günlük ortalama gelir düzeylerinin kentlerin verdikleri göç oranlarına dönemsel (kısa-uzun) mekânsal etkilerinin ortaya çıkarılması amaçlanmaktadır. Çalışma sonucunda, kentsel düzeyde göç hareketliliğindeki sorunsallıkların giderilebilmesi için sosyal inovasyon ve artımsal inovasyon faaliyetlerinin uygulanabilirlik seviyelerinin artırılmasının önemli olduğu belirlenmektedir.

Anahtar Sözcükler: İç-Göç, sosyal inovasyon, artımsal inovasyon, dinamik mekânsal panel veri analizi

\begin{abstract}
Internal-migration mobility, which is defined as individual / collective relocation due to social, sociocultural, economic and political reasons within the borders of the country, creates urban / regional problems and disrupts national sustainability. Irregular and uncontrolled migration mobility causes cities to lose their habitability characteristics and creates different urban problems (such as traffic, employment, cultural accessibility) as a result of the heterogeneous structure of the population distribution. Urban problems are prevented by increasing innovation activities at the urban/national levels. Within the scope of the article, it is aimed to reveal the periodic (short and long) spatial effects of incremental innovation indicators (exports, entrepreneurship and daily average income level and etc.) and social innovation indicators (number of people receiving social services and etc.) to urbans'migration based on 2011-2018 periods. It is determined that it is important to increase the applicability levels of social innovation and incremental innovation activities in order to overcome the problems in migration mobility at the urban level
\end{abstract}

Keywords: Internal migration, social ilnnovation, incremental innovation, dynamic spatial panel data analysis

Önerilen atıf şekli: Terzioğlu, M.K., Yücel, M. A. ve Gençler, A. (2021). Sosyal İnovasyon ve Artımsal İnovasyon Çerçevesinde İç-Göç Olgusunun Dinamik Mekânsal Etkileşimi. Sosyal Güvenlik Dergisi (Journal of Social Security). 69-94

• Geliş Tarihi/Received: 30/03/2021 • Güncelleme Tarihi/Revised: 01/06/2021 • Kabul Tarihi/Accepted: 14/06/2021

* Doç. Dr., Trakya Üniversitesi, İktisadi ve İdari Bilimler Fakültesi, Ekonometri Bölümü, kenanterzioglu@trakya.edu.tr

** Trakya Üniversitesi, Sosyal Bilimler Enstitüsü, Ekonometri Anabilim Dalı, maliiyucell@gmail.com

*** Prof. Dr., Trakya Üniversitesi, İktisadi ve İdari Bilimler Fakültesi, Çalışma Ekonomisi ve Endüstri İlişkileri Bölümü, ayhangencler@trakya.edu.tr 


\section{GíRIŞ}

İletişim ve ulaşım teknolojilerindeki gelişmelerle birlikte kolay, hızlı ve güvenilir bir şekilde bireysel/kitlesel yer değişimi sağlanabilmektedir. Siyasal, toplumsal, ekonomik, kültürel vb. gibi faktörlerle bireylerin/toplulukların bulundukları yerleşim yerlerinden ayrılarak başka yerleşim yerlerine gitme eylemi olarak tanımlanan göç hareketliliği, ekonomik ihtiyaçlara ve firsatlara ulaşılması açısından önem arz etmektedir (Parrado ve Cerrutti, 2003). Göç olgusu, iktisadi, sosyal ve kültürel yaşama etkide bulunan temel değişim araçları arasında görülmektedir. Farklı nedenlerden ortaya çıkabilen ve sonuçları toplumsal yapıyı değiştirebilme yetisine sahip bir faktör olan göç olgusu, toplumsal bir sorun olarak ortaya çıkmakta ve ileriki dönemlerde de artarak devam etmesi öngörülmektedir. Bu çerçevede, göç alan/veren ülkelerin/bölgelerin/kentlerin, göç aldıktan/verdikten sonra karşı karşıya kaldıkları sonuçların ortaya çıkartılarak belirgin şekilde anlaşılmasının sağlanması ve ülke kalkınmasında atılacak adımların belirlenmesi için politika önerilerinin oluşturulması gerekmektedir. Ülke ekonomilerine ve kalkınma düzeylerine doğrudan etkisi bulanan ve geniş bir tanımı olan uluslararası göçün aksine; bireylerin/kitlelerin kendi ülke sınırları içerisinde bir kentten/bölgeden diğer bir kente/bölgeye hareketi olarak tanımlanan iç-göç (kırdan kıra, kırdan kente, kentten kıra ve kentten kentte olarak değişen), daha iyi yaşam koşulları arama, kaliteli eğitim isteği, sağlık hizmetlerine erişilebilirlik, yeşil alan eksikliği, teknolojik erişilebilirlik, ulaşım hizmetleri, politik/etnik/dini görüş farklılıkları vb. gibi nedenlerden ötürü gönüllü ve zorunlu şekilde gerçekleşebilmektedir. 1950 dönemi itibariyle Türkiye'de az gelişmiş veya gelişmekte olan bölgelerden gelişmiş bölgelere doğru başlayan göç akımı, genelde kırdan kente doğru mesleki hareketlilik ve istihdam odaklı gerçekleşmekteyken, 1970 dönemi itibariyle kırsal alanlardan kentsel alanlara yapılan göç hareketliliğginde azalış görülmekte ve 1980 dönemi itibariyle kentsel alanlardan diğer kentsel alanlara doğru gerçekleşen göç hareketliliğinde artış yaşanmaktadır. Serbest piyasa ekonomisinin uygulanması, özelleştirme, iletişim ve ulaşım koşullarının geliştirilmesi, bireyselci yaklaşım ve davranışlarının gelişmesiyle birlikte toplumsal bilincin önem derecesinin artması sonucu 1980 ve 1990 dönemlerinde Türkiye'deki iç göç hareketliliğinde artış gözlenmektedir (Yüksel vd. 2016: 36; Sigeze ve Balli, 2006: 293).

Düzensiz göç hareketliliği, homojen olmayan nüfus dağılımı, çarpık kentleşmenin yaygınlaşması, suç oranlarında artış yaşanması, iklim değişikliğinin kitleler üzerinde etkisini artması, uygun olmayan çalışma ve barınma koşulları bulunması, eğitime erişilebilirliğinin adil olmaması vb. gibi sosyal zorluklar ve küresel rekabet edilebilirliğinin artması, gelir dağılımının adil olmaması, işsizlik düzeylerinin artması vb. gibi ekonomik zorluklar ülkelerin sürdürülebilirliğini sekteye uğratmaktadır. Gelişmiş ülkeler politika düzlemlerinde toplumların/bireylerin sosyal ihtiyaçlarını karşılamak ve sosyal/toplumsal sürdürülebilirliği sağlamak için yenilikçi ve kapsayıcı çözümler bulmaya çalışmaktadır. Gelişmekte olan ve az gelişmiş ülkeler ise, ekonomik kalkınmaya daha çok önem vermeleri nedeniyle sosyal boyutlarda (eğitim düzeyinin artırılması, yaşam standartlarının yükseltilmesi, toplumsal kaynaklara erişilebilirliğinin yaygınlaştırılması, sağlık erişilebilirliğinin adil olması vb. gibi) kalkınmaya öncelik vermemektedir (Rae, 2006). Resmi ve gayri resmi süreçleri, ilişkileri, sistemleri oluşturmayı hedefleyen (Brennan, 2010) ve sosyal adaletin sağlanmasını, sağlık ve eğitim hizmetlerine erişilebilirliği, cinsiyet eşitliğinin oluşturulmasını ve sosyal hizmetlerin geliştirilmesini amaçlayan (Holmberg ve Sandbrook, 1992) sosyal kalkınma, teknolojik gelişmeler ve değişen toplumsal yapı sürecinde dezavantajlı kitlelere (çocuk, genç, kadın, yaşlı, engelli, yoksullar vb. gibi) eşitlik ve adalet ilkesi kapsamında sosyal olarak sürdürülebilirliğinin sağlanmasını amaçlamaktadır. Sosyal kalkınmanın sağlanabilmesi ve toplumsal değişimlerin oluşturulabilmesi için, bireylerin gereksinim ve sorunları belirlenerek 
verimsiz olan geleneksel modellerin inovatif/yenilikçi olgularla değiştirilmesi gerekmektedir. Ek olarak, göç hareketliliğinin düzensiz olması, sağlık erişilebilirliğinin farklılık göstermesi, yeterli istihdam alanlarının bulunmaması, çok kültürlülüğe uyumun sağlanamaması, bireyselleşmenin artması vb. gibi sosyal ve ekonomik sorunların insanlar üzerinde oluşturduğu fiziksel ve psikolojik etkiler, sosyal hizmetlerin sürekli inovatif/yenilikçi yöntemler oluşturarak çözüm üretmesi gerekliliğini ortaya çıkarmaktadır. Bu kapsamda, yeni sosyal ilişkilerin yaratılması ve sosyal ihtiyaçların karşılanması için yeni hizmet, model, fikir ve süreçlerin uygulanması ve geliştirmesini amaçlayan sosyal inovasyon kavramı ön plana çıkmaktadır. İnovasyon olgusu, toplumsal ve ekonomik gelişmeyi ve bireysel mobilitenin artırılmasını (European Commission, 2013) amaçlarken; sosyal inovasyon olgusu, kamusal veya özel kurumlar yoluyla sosyal ihtiyaçların karşılanması için faaliyetler ve hizmetlerin inovasyon kavramıla entegre edilmesiyle sosyal kalkınmayı hedeflemektedir (Mulgan, 2006: 146). Sosyal inovasyon; yeni fikirleri, stratejileri ve uygulamaları kapsayan bir süreç olarak ifade edilmekteyken, sosyal sorunların çözülmesinde, bireysel-toplumsal ihtiyaçların karşılanmasında ve toplumsal değişimin gerçekleştirilmesinde önem arz etmektedir.

İşgücünün yer değiştirmesi sonucunda ortaya çıkan göç olgusu, nitelik açısından emek arzını genişletebilmesi nedeniyle yerli emeğin ikamesi olmak yerine emeği tamamlayıcı özelliğe sahip olabilmekteyken; işgücü göçü, emeğe kazandırma vasıtasıyla araştırma geliştirme (Ar$\mathrm{Ge})$ faaliyetlerini, girişimcilik faaliyetlerini ve bilgi aktarımı yoluyla inovasyonu teşvik edebilmektedir. Yasal mevzuatlara uygun olarak yapılan düzenli göç hareketliliği, bireyseltoplumsal niteliklerin daha kolay kullanılabilmesine ve bireylerin-toplumların işgücü piyasasına daha kolay uyum sağlayabilmesine neden olabilmekteyken; düzensiz göç haraketliliğinde ise bireysel vasıfların optimum seviyede kullanılması ve uyum sorunu yaşanması gibi sorunsallıklar ortaya çıkabilmektedir. Düzenli göç hareketliliği sonucu nüfusu gençleşen, işgücüne sahip olan, ekonomik faaliyet çeşitliliğini içerisinde barındıran ve sürdürülebilir kalkınması olan kentler/bölgeler, bilimsel ve teknolojik ilerlemelerde ön plana çıkabilmektedir (Nakhoul, 2014). Adil olmayan gelir dağılımı, bölgeler arası gelişmişlik/kalkınmışlık farkı, artan işsizlik, yoksullaşma ve etkin bir rekabet ortamının bulunmaması üretim faktörleri arasında yer alan girişimcilik faktörünü piyasa ekonomilerinde ön plana çıkarmaktadır (Paleno ve Kleiner, 2000). Girişimciliğin temelinde yer alan inovasyon süreçlerinde bilim ve teknolojideki gelişmelerin piyasa ekonomisi üzerine olumlu etkileri olması nedeniyle kalkınma üzerine odaklanılmaktadır. Artımsal inovasyon faaliyetleri ile arasında doğrusal ilişki bulunan girişimcilik, kalkınmışlık düzeyi yüksek olan kentlerde/bölgelerde ön plana çıkmaktadır. İnovasyon sürdürülebilir bir büyüme sağlayabilmekteyken, bilgi birikiminin hızlı artması farklı kavramları ve kavrayışları ortaya çıkarmakta ve artan bu bilgiyle kurumların amaçları, yapıları, işlevleri yenilenmek zorunda kalmaktadır (Rogers, 2003).

Makale kapsamında, 2011-2018 yılları baz alınarak, sosyal inovasyon göstergesi olarak ele alınan kentlerdeki sosyal hizmet alan kişi sayısının ve artımsal inovasyon göstergeleri olarak ele alınan kentlerin ihracat, girişimcilik ve günlük ortalama gelir düzeylerinin kentlerin verdikleri göç oranlarına olan etkilerinin yanı sıra verilen göç hareketliliğinin dönemsel (kısa-uzun) olarak mekânsal bir dağılıma sahip olup olmadığının araştırılmasıyla birlikte literatüre katkı yapılması amaçlanmaktadır. Ortak sınır ilişkisine sahip ülkelerin-bölgelerinkentlerin benzer politikalar gösterebilmesi nedeniyle mekânsal ilişkilerin gözetilmesi gerekliliğini ortaya çıkarmaktadır (Yücel, 2021). Bu kapsamda, iç-göç sorunsalı olgusunun sosyal ve artımsal inovasyon göstergeleriyle arasındaki etkileşiminin ortaya çıkarılmasında gerçekleştirilen modelleme-tahminleme süreçlerinde kullanılan yöntem çeşitliği farklı 
sonuçlar ortaya koymaktadır. Modelleme ve tahminleme aşamalarında kullanılan en uygun ve etkin ekonometrik yöntemin tanıtılması fikrine dayalı olarak gerçekleştirilen çalışmada, daha önce ele alınan klasik panel yöntemler veya yatay kesit/panel mekânsal yöntemler yerine dinamik sürecin dahil olduğu dinamik mekânsal panel veri yöntemi tanıtılmakta ve bu yöntemin kullanılmasıyla elde edilen sonuçlara ait politika süreçlerinin tasarlanması ve etkinliklerinin sorgulanması gerekliliği ortaya koyulmaktadır. Model yapısına ilişkin hipotezlere dinamik etkiler ve mekânsal etkiler dahil edilerek iç-göç sorunsalının ve sosyal ve artımsal inovasyon göstergeleri arasındaki mekânsal yapının değerlendirilmesi gerekliliğine vurgu yapılmaktadır. Ek olarak, yapılan literatür taraması sonucunda hem mekânsal ilişkilerinin gözetilerek iç-göç sorunsalının sosyal ve artımsal inovasyon göstergeleriyle değerlendirilmesiyle ilgili hem de dinamik mekânsal panel veri yaklaşımı ile ilgili neredeyse yok denecek kadar az çalışmaya rastlanıldığından, çalışma kapsamında modele ilişkin ayrıntılı teorik bilgi verilerek hem iç-göç sorunsalı hem de diğer alanlarda yapılması muhtemel çalışmalara yön gösterilmesi amaçlanmaktadır. Makale kapsamında, birinci bölümde iç-göç olgusunun sosyal ve artımsal inovasyon göstergeleriyle ilişkisine değinildikten sonra ikinci bölümde ele alınan ekonometrik modelin teorik yapısı hakkında bilgi verilmekte ve son bölümde sosyal ve artımsal inovasyon göstergelerinin iç-göç sorunsalı üzerindeki mekânsal etkiler belirlenerek politika önerilerine değinilmektedir.

\section{I- KAVRAMSAL ÇERÇEVE}

Sürdürülebilirlik kapsamında toplumsal yapı insanların, beslenme, sağlık, güvenlik, eğitim, barınma vb. gibi temel ihtiyaçlarının karşılanması, bilgiye erişimin kolaylaşması, sosyokültürel mirasın korunup sağlıklı bir şekilde aktarımının sağlanarak refah/yaşam düzeyinin artırılması ve bu düzeyin korunması olarak bilinmektedir. Gelişmiş ülkeler, sürdürülebilir kalkınma kapsamında insani ihtiyaçların (beslenme, barınma vb. gibi) erişilebilirliğinin artırılması, düzensiz göç hareketliliğinin dengelenmesi, çarpık kentleşmenin azaltılması, suç oranların kontrol edilebilir seviyelere indirgenmesi vb. gibi sosyal zorluklar ile mücadele edebilmek amacıyla sosyal kalkınma politikalarına önem vermektedirler. Bu kapsamda, sosyal kalkınmanın sağlanabilmesi için toplumsal ve sosyal zorluklara inovatif çözümler üreten, kültürel, etnik, ekonomik ve sosyal farklıların çözümlenme noktasında önemli olan sosyal inovasyon kavramı ön plana çıkmaktadır.

\section{A- Sosyal İnovasyon}

Sosyal, kültürel, sağlık ve istihdam politikalarının yanı sıra eğitim/öğretim, beceri geliştirme, iş desteği, sanayi politikası, kentsel gelişim vb. konulara yeni bakış açısı sağlayan sosyal inovasyon, ihtiyaçların karşılanması amacıyla yeni ve verimli sosyal ilişkilerin kurgulanması ve uygulanması olarak tanımlanabilmektedir (Mulgan, 2006: 146). Sosyal etkileşim sürecine etkide bulunarak sosyal taleplerin çözülmesine katkıda bulunabilen sosyal inovasyon, bireysel refahın geliştirilmesine de öncü olabilmektedir. Sosyal inovasyon, toplumsal amaç ve araçlara yenilikçi, kapsayıcı ve bütüncül bakmaya destek vermekte ve bireysel hareket etme kapasitesini artıran yeniliklerin oluşmasını sağlamaktadır. Toplumsal dezavantajı olan insanlar sivil toplum örgütlerine, yerel topluluklara ve kamusal hizmetlere güvenmektedirler. Sosyal etkileşimler hem kamu sektörü hem de pazarlar için bir firsat oluşturmakta ve ürünlere/hizmetlere bireysel ulaşılabilirliğinin adil olmasını sağlayarak toplumsal birlikteliğinin oluşmasını sağlamaktadır. Bu kapsamda, yeni karşılanan sosyal ihtiyaçların belirlenmesi, çözüm önerilerinin geliştirilmesi, etkinlik düzeylerinin değerlendirilmesi ve ölçeklendirilmesi olmak üzere dört süreçten oluşan sosyal inovasyon, toplumsal birlikteliğin oluşturulmasında ve sosyal sürdürülebilirliğin sağlanmasında önemli bir etmen olarak görülmektedir. Toplumsal talep perspektifi, sosyal, ekonomik ve çevresel konuların 
entegrasyon yoluyla bir bütün olarak toplumsal yeniliklere odaklanılmasını ifade etmektedir. Geleneksel olarak piyasa veya mevcut kurumlar tarafindan ele alınmayan ve toplumdaki dezavantajlı gruplara yönelik sosyal taleplere cevap veren sosyal inovasyon, toplumsal birlikteliği etkileyen (göçmenlik, yaşlılık, yoksulluk vb. gibi) sorunlarla mücadele edilmesinde yeni yaklaşımlardan yola çıkarak toplumsal talebin gelişmesine yardımcı olmaktadır. Toplumsal birlikteliğin sağlanmasında ve sosyal inovasyonun gerçekleştirilmesinde kamusal/özel kurumların sosyal hizmetlerin geliştirilmesi yönünde atacakları adımlar önem arz etmektedir. Sosyal inovasyon, bölgesel/yerel düzeyde toplumların ekonomik ve sosyal sorunlara ortak çözümlerin bulunmasını ve vatandaş katılımının yüksek olmasını amaçlamaktadır. Multi-disipliner uygulama alanı olan sosyal inovasyon, düzensiz göç hareketliği, sosyal dışlanmışlık, kentsel dönüşüm, bölgesel stratejiler, sosyo-ekonomik vb. gibi sorunlar ile mücadele etme konusunda itici güç olmakta ve sosyal ihtiyaçların karşılanması için inovatif kararların alınmasına, yerel paydaşların sosyal-kültürel-toplumsal zorluklara yerel karşılıkların oluşturulmasına ve kamusal maliyetlerin azalmasına destek sağlamaktadır (European Commission, 2013). Sosyal inovasyonun analiz edilebilmesi için yerel ve bölgesel dinamiklere önem verilmesi ve komşu kentlerin/bölgelerin birbirini etkileyebilmesi nedeniyle mekânsal ilişkilerin gözetilerek inceleme yapılması gerekmektedir. Makale kapsamında, kentlerin sosyal inovasyon düzeylerini belirlemek amacıyla kullanılan sosyal güvenlik değişkeni; tüm maddi kayıpların karşılanması ve vatandaşların güvence altına alınması ile sorumlu bir kamusal alanı ifade etmektedir. Sosyal güvenliğin yapısını, sağlıkla ilgili gelir kaybı yaratan unsurlar, işsizlik, iş kazaları, mesleki hastalıklar, aile yardımları vb. gibi durumlar oluşturmaktadır. Karabulut ve Polat (2007), iç göçün nedenlerinin temel hizmetler olan sağlık ve eğitim eksikliği, sosyal faaliyetlerin yokluğu, zorlayıcı iklim koşulları ve daha iyi şartlarda daha yüksek ücretle çalışma umudu olduğunu ifade etmektedirler. Demirkaya ve Artvinli (2011), yoksulluğun iç göç için en önemli neden olduğunu savunmaktadır. Çoban (2013), eğitim, iş olanakları, sağlık hizmetleri ve çevresel faktörlerin iç göç üzerinde önemli bir rol oynadığını ileri sürmektedir. Tutar ve Özyakışır (2013), iç göçün belirleyicilerin işsizlik, yoksulluk, sosyal güvenlik faktörleri olduğunu vurgulamaktadır. Çatalbaş ve Yarar (2015), terör, bölgenin gelişmişlik düzeyi, enflasyon oranı, istihdam oranının bölgesel göç üzerinde etkili olduğunu ifade etmektedir. Doğan ve Kabadayı (2015), iş firsatları, eğitim, sağlık koşulları ve güvenliğin iç göç için bazı kentleri cazibeli kıldığını belirtmektedir. Terzioğlu ve Yaşar (2018), suç olgusunun artması sonu göç olgusunda hareketlilik yaşanabileceğini vurgulamaktadır.

\section{B- Artımsal İnovasyon}

Değişim ve yenilenme sürecini ifade eden inovasyon; bir fikri, pazarlanabilir bir ürün/hizmete, yeni/geliştirilmiş bir üretim ve hizmet yöntemine dönüştürme olarak tanımlanmaktadır (Mota ve Scott, 2014). İnovasyon uygulanabilirliğine göre, radikal fikirler sonucu daha önce uygulanmamış ürün, hizmet, süreç ve yöntemlerin geliştirilmesi ve uygulanması olarak ifade edilen radikal inovasyon ve kademe kademe yapılan bir dizi araştırma ve geliştirme faaliyetlerinin sürekli birikerek geliştirilmesi ve uygulanması olarak adlandırılan artımsal inovasyon olmak üzere iki gruba ayrılabilmektedir. Artımsal inovasyon uygulamalarıyla toplumların davranışlarında önemli değişiklere yol açan yeni/geliştirilmiş ürün, hizmet ve yöntemler adım adım geliştirilerek pazara sunulmaktadır. Artımsal inovasyon ülkelerin rekabetçiliğine olanak vermesi nedeniyle sürdürülebilirlik açısından daha verimli olarak değerlendirilmektedir. Sektörel farklılıklara göre sıklıkla uygulanabilmesi ve pazar taleplerine göre şekillenebilmesi nedeniyle pazar yapısını değiştirebilen artımsal inovasyonun, ilerlemeler kademe kademe yapılmasına rağmen, etkisi 
daha büyük olmaktadır. Artımsal inovasyon hem kullanıcı taleplerinin bir sonucu olarak belirtilmekte (Sarja, 2015) hem de mevcut ürünlerdeki (ürün/süreç/hizmet) iyileştirmeleri/geliştirmeleri kapsayarak pazardaki ürünlerin potansiyelini artırmakta ve üreticilerin pazar baskınlığını desteklemektedir (Tushman ve Anderson, 1986). Türkiye'de yer alan küçük ve orta ölçekteki işletmelerin (KOBİ), sınırlı kaynaklara sahip olması (Terziovski, 2010) nedeniyle artımsal inovasyonu uygulama eğiliminde oldukları gözlemlenmektedir. Artımsal inovasyon küçük ve orta işletmelerin teknolojik eksiklerini gidererek ve yüksek verimlilik sağlayarak büyük işletmeler ile olan farkların kapatılmasını sağlayabilmektedir (Jansen vd., 2006; Xu, 2015). Teknolojik gelişmişliği yakalamak için yeterli teknik ve finansal temele sahip olmayan işletmelerde, artımsal inovasyon uygulamalarıyla kademe kademe/adım adım inovasyon birikimine destekte bulunularak teknolojik değişime yardımcı olunabilmektedir. $\mathrm{Bu}$ nedenle, işletmelerinin başarıya ulaşılabilmesi için artımsal inovasyonu benimsemeleri gerekmektedir (Calabrese vd., 2005; Radas ve Bozic, 2009). Girişimcilik, gelir düzeyi ve uluslararası ticaret edilebilirliğinin artması durumda artımsal inovasyon çıktıları daha verimli olmakta ve kentsel inovasyon da sağlanabilmektedir (Ahuja ve Katila, 2001).

\section{i) Artımsal İnovasyon ve Girişimcilik}

Bölgeler arası gelişmişlik farklarının azalması, işsizliğin azaltılarak toplumun alt ve orta gelir grubunun güçlendirilmesi, refahın arttırılması, teknoloji kullanımının yaygınlaşması vb. gibi etkileri olan girişim ve girişimcilik olguları, yeni ürünlerin üretilmesi ve süreçlerin geliştirilmesi, ihracat pazarlarının ve hammadde kaynaklarının bulunmasıyla ve yeni birleşimlerin oluşumuyla ekonomik düzenin tekrardan kurgulanmasını sağlayarak, kalkınma için ekonomik bir temel yaratmakta ve sosyo-ekonomik gelişmenin işleyişini verimli hale getirmektedir (Döm, 2006). Üreticinin uzun vadede rekabet gücünü ve performansını arttırarak ekonomik gelişme, uluslararası ticaret ve bölgesel refah getiren, teknolojik ilerleme ve gelişmeyi birbirine entegre eden ve kademe kademe gerçekleşen artımsal inovasyonu geliştirmek için araştırma-geliştirme faaliyetleriyle birlikte yeni bilgiler/süreçler oluşturulmakta ve başka alanlarda yapılan çalışmalardan ilham alınarak yenilikler sağlanabilmektedir. Kentsel/bölgesel araştırma-geliştirme faaliyetlerine önem verilmesi uygun işgücünü oluşturmaktayken; nitelikli işgücü ihtiyacını artırmaktadır. İhtiyaç duyulan vasıflı elemanların yetiştirilmesi için gereken sürenin uzaması ve yetiştirme maliyetinin yükselmesi emeğin diğer kentler/bölgelerden karşılanmasını yani işgücü göçünü beraberinde getirmektedir. $\mathrm{Bu}$ durumda, kentlerin/bölgelerin eğitim, bilim, bilgi teknolojileri ve araştırma-geliştirme faaliyetlerine verdiği önem ile sunduğu olanaklar ön plana çıkmaktadır. Artımsal inovasyonun merkezinde yer alan araştırma-geliştirme uygulamalarına yapılan yatırımlar, artan verimlilikle birlikte yükselmekte ve kentsel verimlilik sonucu ortaya çıkan bu yatırımlar kentlerin yaşam kalitesini optimum seviyeye getirmektedir (Fischer ve Wang, 2011: 56). Kentsel verimliliği arttırmak için endüstriyel alanların oluşturulması sonucu ortaya çıkan yeni iş olanakları verimlilik ve inovasyon ilişkisini ortaya çıkarmaktadır. Endüstriyel bölgelerde üretim maliyetinin düşmesiyle birlikte üreticiler yüksek verimlilik elde edebilmekte ve yeni yaratılan iş firsatlarıyla işsizlik azaltılabilmektedir. Ek olarak, kentlerdeki artımsal inovatif faaliyetler üretim performansını artırarak kentlere rekabet edilebilirlik kazandırabilmektedir. Makale kapsamında, artımsal inovasyon göstergelerinden birisi olarak kentlerdeki girişimcilik faaliyetleri değişkeni kullanılmaktadır. Filiz ve Çemrek (2005), kişi başı gayri safi yurtiçi hasıla ve tüketim harcamaları değişkenlerinin iç göçün yoğun yaşandığı bölgelerdeki farklılıklara neden olduğunu savunmaktadır. Ceritli, Sunar ve Demirci (2005), iç göçün en önemli nedeninin işsizlik olduğunu belirmektedir. Pazarlığlu 
(2007), iç göçün engellenebilmesi için gelir dağılımındaki eşitsizliğin ve kentler arasındaki kalkınmışlık farklarının ortadan kaldırılması gerekliliğini belirtmekteyken; bazı kentlere iç göçün ana belirleyicisinin ise insanların etnik kökenleriyle ilgili olduğunu vurgulamaktadır. Gezici ve Keskin (2008), bölgesel eşitsizliklerin iç göçe neden olduğunu ifade etmektedir. Bülbül ve Köse (2010), az gelişmiş Doğu ve Güneydoğu bölgelerinde yer alan kentlerden Batı bölgelerindeki kentlere göç hareketliliğinin nedeni olarak girişimciliğin önemine vurgu yapmakta ve bölgelerin sermaye birikimi açısından firsat yaratmasının girişimciler açısından teşvik edici olduğunu ileri sürmektedir. Bunun yanında, bölgelerdeki sermaye birikiminin araştırma-geliştirme faaliyetlerine olanak sağlayabildiğini ve özellikle beşerî sermayesi gelişmiş nüfus tarafından ilgili bölgeye göç hareketliliğinin cazip hale geldiğini belirtmektedir. Zeren ve Tülümce (2013), sanayileşmeyle birlikte artan araştırma-geliştirme faaliyetleri sonucunda üretimin artmasının ve ekonomik kalkınma ile refah seviyesinin yükselmesinin net iç göç seviyesini etkilediğini vurgulamaktadır. Prystrom (2017), yerel yönetimlerin inovasyon girişimlerinin aktif katılımı olmadan başarı şansının olmadığını belirtmektedir. Terzioğlu vd. (2018), teknolojik gelişmelerin, eğitim düzeyi ve girişimcilik faaliyetlerinin kalkınma ile doğru orantılı ilerleyeceğini ve ülkelerin kalkınma düzeyinin artması durumunda göç olgusunun azalacağını ifade etmektedir.

\section{ii) Artımsal İnovasyon ve İhracat}

Artımsal inovasyonun dışsal olarak görüldüğü ve artımsal inovasyonun ihracatı doğrudan etkilediğine dayanan ilk görüş ve açık ekonomilerde artımsal inovasyonun düzeyinin içsel hale getirilerek, artımsal inovasyon faaliyetlerinde uluslararası ticaretin dinamik etkilere sahip olduğunu ifade eden ikinci görüş olmak üzere ihracat ile artımsal inovasyon arasında iki farklı ilişki bulunmaktadır (Lachenmaier ve Woessmann, 2004). İlk görüşteki temel düşünce, gelişmiş ülkelerde bulunan iktisadi avantajlar nedeniyle dünyanın büyük bir bölümünün inovatif ürün/hizmetleri ihraç etmesi olarak belirtilmektedir. Diğer bir ifadeyle, ülkelerin ihracat ve gelir düzeylerini artırması için ülkelerin sürekli inovatif faaliyetler geliştirmesi ve uygulaması gerekliliği vurgulanmaktadır. İkinci görüş ise, işletmelerin büyüklükleri ile artımsal inovasyon eğilimleri arasında $U$ şeklinde bir ilişki olduğu ve artımsal inovasyon eğiliminin personel sayısı ve işletme büyüklüğü ile arttığı ancak, daha sonra işletmelerin yeniden yapılanmalara girebilmeleri nedeniyle düşüş yaşandığı temeline dayanmaktadır (Aralica vd. 2008). Etkin, verimli ve planlı bir şekilde yönetilen artımsal inovasyon, yeni ürün ve hizmet ihracatının artmasına yol açmaktadır. Monferrer vd. (2012), artımsal inovasyon ile ihracat faaliyetleri arasında pozitif bir ilişki olduğunu belirtmektedir. Artımsal inovasyon politikaları, küçük ve orta işletmeler başta olmak üzere işletmelerin araştırma ve geliştirme yatırımlarının artmasına destek olmaktadır. (Karbowski ve Prokop 2020). Ülkelerin rekabet edilebilirliği, ilk aşamada; az gelişmiş ülkelerin inovasyonu diğer ülkelerden ithal etmesi, ikinci aşamada; gelişen ülkelerin teknoloji ve hizmet inovasyonunu benimseyerek yerel kaynakları daha verimli hale getirmesi (artımsal inovasyon) ve üçüncü aşamada; gelişmiş ülkelerin rekabet gücü kazanabilmek amacıyla radikal bir şekilde inovasyon faaliyetlerini gerçekleştirmesi olmak üzere üç aşamada gerçekleşmektedir (Porter, 1990). Ek olarak, artımsal inovasyon, inovasyon politikalarının yaygınlaştırılmasında ve pazarlanabilirliğinde önemli rol oynamaktadır (Talke, 2007).

\section{iii) Artımsal İnovasyon ve Ortalama Kazanç}

Yoksul bireylerin büyük bir çoğunluğu kırsal alanlarda doğduğu/yaşadığı bilinmesine rağmen daha iyi ücret, daha imkân ve işsizlik nedeniyle farklı sektörlerde çalışmak amacıyla 
kırdan kentlere göç etmekte ve bunun sonucumda kentsel nüfus artmaktadır. Bu durum, kentlerdeki yoksul sayısının nüfus artışından daha hızlı artmasına ve göç edenlerin gecekondu mahallelerinin büyümesine neden olmaktadır (Oosterlynck vd., 2013, s.16). Ekonomik İş birliği ve Kalkınma Örgütü (OECD) 2011-2020 dönemi kentsel politika incelemelerinde, yoksulluk ile ilgili kentleşmenin kentsel nüfus üzerinde etkisinin olduğu ve yeni kent sakinlerinin eski kent sakinlerine göre daha yoksul olma eğiliminde oldukları belirtilmektedir (OECD, 2020: 1-12). Makale kapsamında, artımsal inovasyon göstergelerinden birisi olarak kullanılan kazanç değişkeni, kişilerin hayatlarını idame ettirebilmek için ihtiyaç duydukları mal ve hizmetleri satın almak adına çalışarak elde ettikleri parasal değeri ifade etmektedir. Bölgeler arasındaki gelişmişlik ve kaynak dağılımı farklılıklarından ötürü verimliliğin kentler/bölgeler arasında farklılık gösterdiği ve ortalama günlük kazançlar açısından da kentler/bölgeler arasında büyük farklılıklar olduğu görülmektedir (Bolukçu, 2020: 12). Bu durum, kentler/bölgeler arası ortalama günlük kazancın arttırılması için farklı meslek, eğitim ve yaş gruplarının göç etmesine neden olmaktadır (TÜİK, 2018). Terzioğlu vd. (2018), ekonomik büyümenin yavaşlaması sonucu yoksulluk ve gelir dağılımı eşitsizliklerinin artacağını ve bu nedenle göç olgusunda hareketliliğin artabileceğini belirtmektedir. Çoban (2013), kentsel ve kırsal alanlar arasında sosyo-ekonomik ve endüstriyel kalkınma açısından eşitsizlik derecesi arttıkça bireylerin göç etme olasılığının daha da arttığını ifade etmektedir. Yamak ve Yamak (1999), bölgesel gelir eşitsizliğinin iç göç üzerinde önemli bir etkiye sahip olduğunu vurgulamaktadır. Özmucur ve Silber (2002), kırsal alanlardan kentsel alanlara yapılan iç göçün dengeleyici bir mekanizma olarak hareket etmek ve açığı kapatmaktan ziyade gelir dağılımı eşitsizliklerini artırdığını belirtmektedir. Gökhan ve Filiztekin (2008), gelir farklılıkları ve işsizliğin iç göçü etkileyen en önemli faktörler olduğunu savunmaktadır. Terzioğlu vd. (2018), temel ihtiyaçların rahat karşılanmasını, sağlıklı bir ortamda yaşam sürdürülmesini ve kalkınma için yeterli eğitim olanaklarından faydalanılmasını ifade eden beşerî sermaye düzeylerindeki artış yaşanması durumunda büyüme ve kalkınmanın olumlu yönde etkileneceğini ve göç olgusunda hareketliliğin azalacağını belirtmektedir. Lucas (2015), iç göçün istihdam firsatları, kazanç farklılıkları, olanakların mevcudiyeti ve kalitesi, eğitim eşitsizliği, zorunlu göç ve şiddet olmak üzere birkaç nedeni olduğunu belirtmektedir. İstihdam firsatları göç için önemli bir etmen olarak görülmekteyken; çoğu endüstriyel bölgeler kentsel alanlarda bulunmaktadır. Bu nedenle işgücü kırsal alanlardan kentsel alanlara doğru hareket etmektedir. Lucas (2015), kazanç farklılıkları nedeniyle ülke çapında iç göçün gerçekleşebileceğini ifade etmektedir. Tanfer (1983), tarımsal üretimin yavaş büyümesinin Türkiye'de iç göç hareketinin artmasına katkıda bulunduğunu belirtmektedir.

\section{II- DİNAMİK MEKÂNSAL PANEL VERİ MODELLEMESİ}

Mekânsal etkileşim ve mekânsal heterojenlikten kaynaklanabilen mekânsal etki hem coğrafik hem de sosyo-ekonomik uzaklıklar nedeniyle ortaya çıkabilmektedir (Le Gallo, 2002). Mekânsal etkileşim, uzaysal/konumsal alanda olan bir noktanın başka bir konumda olan nokta ile arasındaki etkileşim olarak tanımlanmaktadır (Anselin 1988: 11). Baz alınan konuma bağlı olarak ortaya çıkan ve baz alınan konum ile komşu konum arasındaki ilişkiyi tanımlayan mekânsal etki, yatay kesit bağımlılığı kapsamında komşu konumdaki korelasyonu ifade eden mekânsal bağımlılığa (otokorelasyon) ve yatay kesit heterojenliği kapsamında ilgilenilen değişkenin bir konumdan diğerine sabit olmayan varyansını ifade eden mekânsal heterojenliğe sahip olabilmektedir (Anselin vd., 2008: 5). Bu kapsamda, mekânsal birimlerin homojenlikten uzaklaşmasına neden olan mekânsal heterojenlik, 
Sosyal İnovasyon ve Artımsal İnovasyon Çerçevesinde

İç-Göç Olgusunun Dinamik Mekânsal Etkileşimi

ilgilenilen alan üzerindeki noktalarda farklı ilişkinin gözlenmesi olarak tanımlanabilmekteyken, doğrusal regresyon modelinde, $i=1,2, \ldots, n$ gözlemleri için $(1 \times K)$ boyutlu açıklayıcı değişken matrisi $x_{i}$, bağımlı değişken vektörü $y_{i}$, parametre vektörü $\beta_{i}$ ve hata terimi $\varepsilon_{i}$ olmak üzere mekânsal heterojenlik $y_{i}=f_{i}\left(x_{i} \beta_{i}, \varepsilon_{i}\right)$ şeklinde ifade edilebilmektedir (Lesage, 1999, s.7). Rassal değişkenin komşu konumlarda gözlenen değerleri arasındaki korelasyonun sıfırdan farklı olması mekânsal otokorelasyon olarak tanımlanabilmekteyken (Darmofal, 2006: 6), i ve $j$ konumları arasındaki korelasyona $\operatorname{Cov}\left(y_{i}, y_{j}\right)=E\left(y_{i} y_{j}\right)-E\left(y_{i}\right) E\left(y_{j}\right) \neq 0, \forall i \neq j$ ifadesi ile ulaşılabilmektedir. Ek olarak, $i$ ve $j$ konumları arasındaki korelasyon sıfırdan farklı olması durumunda mekânsal açıdan ilişki (değer benzerliği ile konum benzerliğinin uyumlu) olduğu söylenebilmektedir. Rassal değişken için düşük/yüksek olan değerlerin kümelenme eğiliminde olduğu durumda pozitif mekânsal otokorelasyon, baz alınan konumun komşu konumlar tarafından çok farklı değerler ile çevrelenmiş olduğu durumda negatif mekânsal otokorelasyon ve değer dağglımlarının belirli bir kalıba uymadığı ve mekânsal otokorelasyodan söz edilemediği durumda rassallık durumu olmak üzere üç farklı mekânsal otokorelaasyon bulunmaktadır.

Mekânsal ekonometride konumdan kaynaklı ilişki yapısı coğrafi ağırlıklandırma veya sosyoekonomik ağırlıklandırma teknikleriyle matris formu kullanılarak gösterilebilmektedir. $\mathrm{Bu}$ nedenle mekânsal etkileşimi belirleyebilmek için, kurulan ekonometrik modele mekânsal bağıntının dahil edilmesi gerekmektedir. Bu durum, gözlemler arasında mekânsal etkileşim modellenmesi nedeniyle her bir gözlemin bir dizi komşu gözlemle bağlantılı olduğu ve dışsal mekânsal kalıba uygun olan mekânsal ağırlık matrisiyle sağlanabilmektedir. Bu kapsamda, sonlu-negatif olmayan, stokastik bir süreç içeren ve $N \times N$ boyutlu simetrik-kare olan pozitif mekânsal ağrılık matrisinde $(\widetilde{W})$ satır elemanı $i$ konumu ile sütun elemanı $j$ konumu arasındaki etkileşimin gücü, $\widetilde{w}_{i j}$ elemanıyla gösterilmektedir. Gözlemler arasındaki ilişkinin gücü mekânsal ağırlık yapısı ile ifade edilmekteyken, i ve j konumları komşu ise $\widetilde{w}_{i j}=1$, komşu değiller ise $\widetilde{w}_{i j}=0$ olarak elde edilmektedir. Satırları standardize edilmiş komşuluk matrisi mekânsal ağırlık matrisi $w_{i j}=\frac{w_{i j}}{\sum_{j} w_{i j}}$ şeklinde elde edilebilmekteyken, mekânsal ağırlık matrisinin standardize edilmesi otoregresif parametrelerin ve mekânsal bağlantı katsayısının ölçülmesinde ve yorumlanmasında avantaj sağlayabilmektedir (Getis ve Aldsadt 2004: 92-93). İlgilenilen birimlerin özelliğine göre ortak sınır paydaşlığı veya belli bir mesafedeki gözlemlerin mekânsal düzenlemesine dayanan coğrafi ağırlıklandırma, sınırdaşlığa ve uzaklığa bağlı olarak belirlenmektedir (Anselin ve Bera, 1998: 243). Sınırdaşlığa bağlı ağırlıklandırmalarda mekânsal birimler arası ilişki, sınırların ayırt edilebilir harita üzerinden konuma dayalı olarak belirlenmesiyle oluşturulmaktadır. Ortak sınıra sahip alanlar ve birbirini çevreleyen alanlar için bitişik alanların ortak kenar paylaşması üzerine kurulan kale komşuluğu, bitişik alanların ortak bir köşe paylaşması üzerine kurulan fil komşuluğu ve bitişik alanların ortak bir kenar ve köşe paylaşması üzerine kurulan vezir komşuluğu olmak üzere üç komşuluk tanımı bulunmaktadır (Terzioğlu vd., 2020). Ek olarak, mekânsal ilişkilerinin uzak olması durumunda açıklayıcılığını yitirmesi nedeniyle mekânsal ağırlık matrisinin ortak köşe ve kenarın paylaşılması anlamına gelen vezir komşuluğu düzenine göre oluşturulması daha kapsayıcı sonuçlar vermektedir.

Yatay kesit yapıdaki çalışmaların aksine daha geniş modelleme olanağı sunan mekânsal panel yapılar, son dönemlerde gelişerek ve dinamik regresyon modellerle birlikte entegre edilerek mekânsal ekonometri çalışmaların temelini oluşturmaktadır. Bu kapsamda, zaman 
içinde her bir mekânsal birim üzerindeki gözlemler arasındaki serisel bağımlılığın bulunması, zamanın her noktasındaki gözlemler arasındaki gözlemler arasındaki mekânsal bağımlılığın bulunması, gözlemlenemeyen mekânsal ve/veya zaman dönemine özgü etkilerinin bulunması, mekan ve/veya zaman yapılarının gecikmesi alınmasıyla birlikte daha fazla bağımsız değişkenlerin içselliği içermesi nedeniyle mekan-zaman boyutlu dinamik yapıdaki modellemeler, mekânsal yayılma etkilerin incelemesinde daha tutarlı sonuçlar verebilmektedir. Mekânsal panel veri modellerinin bağımlı-bağımsız değişkenlerin gecikmelerin alınmasıyla birlikte oluşturulan dinamik mekânsal panel veri modelleri, statik modellerin aksine doğrudan ve dolaylı etkilere ait sonuçları göstererek daha kapsayıcı sonuçlar vermektedir (Demirkıran vd., 2020). Bu kapsamda, bağımlı değişkenin $\left(Y_{t-1}\right)$ ve mekânsal etkileşimi ifade eden değişkenin $\left(W Y_{t-1}\right)$ gecikmeleri alınarak oluşturulan dinamik mekânsal panel veriye (DSPD) ait notasyon;

$$
\begin{aligned}
Y_{t} & =\tau Y_{t-1}+\delta W Y_{t}+\eta W Y_{t-1}+X_{t} \beta_{1}+W X_{t} \beta_{2}+X_{t-1} \beta_{3}+W X_{t-1} \beta_{4}+Z_{t} \theta+v_{t} \\
v_{t} & =\gamma v_{t-1}+\rho W v_{t}+\mu+\lambda_{t}+l_{N}+\varepsilon_{t} \\
\mu & =\kappa W \mu+\xi
\end{aligned}
$$

şeklinde gösterilmektedir. Modelde, $Y_{t}, t$ dönemindeki $(t=1, \ldots, T)$ her mekânsal birim $(i=$ $1, \ldots, N)$ için bağımlı değişkende oluşan $N \times 1$ boyutlu matrisini belirtmekteyken, $X_{t}$, dişsal açıklayıcı değişkenlerin bir $N \times K$ boyutlu matrisini ve $Z_{t}$, içsel açıklayıcı değişkenlerin $N \times L$ bir boyutlu matrisini ifade etmektedir. $W$, mekânsal etkileşimin olduğu birimlerin komşuluk durumun ifade eden, negatif olmayan ve baz alınan konumların kendisi ile komşu olamamaları nedeniyle köşegen elemanları sıfır (0) olan $N \times N$ boyutlu mekânsal ağırlık matrisini göstermektedir. $\delta$, mekân-zaman boylamını gösteren değişkenin $\left(W Y_{t}\right)$, ve $\eta$, mekân-zaman boylamında gecikmesi alınan bağımlı değişkenin $\left(W Y_{t-1}\right)$ yanıt parametreleri olarak ifade edilmekteyken, $L \times 1$ boyutlu $\theta$, modeldeki içsel değişkenlerin yanıt parametresini ve $K \times 1$ boyutlu $\beta_{1}, \beta_{2}, \beta_{3}$ ve $\beta_{4}$ dişsal açıklayıcı değişkenlerin yanıt parametrelerini göstermektedir. Modelde, $N \times 1$ boyutlu $v_{t}$, serisel olarak ve mekânsal düzlemde korelasyonlu/ilişkili olduğu kabul edilen modelin hata teriminin spesifikasyonunu yansitmaktayken, $\gamma$, serisel otokorelasyon katsayısını ve $\rho$ mekânsal otokorelasyon katsayısını ifade etmekte ve $N \times 1$ boyutlu $\mu,\left(\mu=\left(\mu_{1}, \ldots, \mu_{N}\right)^{T}\right)$ mekânsal-birimsel etkileri içermektedir. Diğer taraftan, $\lambda_{t}$, zaman periyoduna $(t=1, \ldots, T)$ özgü etkilerini göstermekteyken, $l_{N}, N \times 1$ boyutlu bir vektörü ifade etmektedir. Son olarak, $\varepsilon_{t},\left(\varepsilon_{t}=\right.$ $\left.\left(\varepsilon_{1 t}, \ldots, \varepsilon_{N t}\right)^{T}\right)$ ve $\xi$ elemanları sirasiyla sifir $(0)$ ortalamaya ve sonlu varyansa sahip $\left(\sigma^{2}\right.$ ve $\left.\sigma_{\xi}^{2}\right)$ olan bağımsız-özdeş dağılmış rastgele değişkenlerin bozulma terimlerini belirtmektedir. Dinamik etkilere sahip mekân-zaman modelindeki değişkenlerin kısmi türevlerinin alınması durumunda kısa dönem etkilerine ait notasyon;

$\left[\frac{\partial Y}{\partial X_{i k}} \ldots \frac{\partial Y}{\partial X_{N k}}\right]_{t}=(I-\rho W)^{-1}\left[\beta_{k} I_{N}+\theta_{k} W\right]$

şeklinde ifade edilmektedir. Modelde alınan kısmi türevler, belirli bir konumdaki belirli bir açıklayıcı değişkendeki değişimin, kısa dönemde diğer tüm birimlerin bağımlı değişken üzerindeki etkisini göstermektedir. Benzer şekilde uzun dönem etkileri;

$\left[\frac{\partial Y}{\partial X_{i k}} \ldots \frac{\partial Y}{\partial X_{N k}}\right]=[(1-\tau) I-(\rho+\eta) W]^{-1}\left[\beta_{k} I_{N}+\theta_{k} W\right]$ 
şeklinde belirlenebilmektedir. Kısa dönem ve uzun dönemleri belirleyebilmek amaciyla yapılan işlemlerin sağ tarafında zaman bağlamının $(t)$ olmaması dolaylı-doğrudan etkilerin zaman bağlamından etkilenmediği şeklinde açıklanabilmektedir (Elhorst, 2012). Makroekonomik politikaların belirlenmesi aşamasında uzun dönemde politika süreçlerinin dengeye ulaşabilmesi ve ilgili politikaların siyasi-kültürel-ekonomik etmenlerden dolayı sekteye uğrayabilmektedir. Bu kapsamda, uzun dönem mekânsal etkilerinin yanı sıra kısa dönem mekânsal etkilerini de analiz süreçlerine dahil eden dinamik mekânsal panel veri yaklaşımı, tutarl1-sapmasız sonuçlar verebilmesi nedeniyle süreçlerin tasarlanması ve yorumlanmasında kapsamlı değerlendirmeler yapılmasına olanak sağlamaktadır (Yücel, 2021).

\section{III- BULGULAR}

Sosyal invoasyon ve artımsal inovasyonun iç-göç üzerindeki dinamik mekânsal etkilerinin ortaya çıkarmak için oluşturulan model kapsamında, kentlerin sosyal inovasyon düzeyinin belirlenebilmesi amacıyla kentlerdeki sosyal hizmet alan kişi sayısı değişkeni ve kentlerin artımsal inovasyon düzeyinin belirlenebilmesi amacıyla kentlerin ihracat rakamları, kentlerdeki girişimcilik sayıları ve kentlerdeki günlük ortalama kazanç değişkenleri kullanılmaktadır. Makale çalışmasında kullanılan değişkenlere ait veriler, 2011-2018 yılları baz alınarak Türkiye İstatistik Kurumu (TÜİK), T.C Aile, Çalışma ve Sosyal Hizmetler Bakanlığı ve T.C. Gelir İdaresi Başkanlığı'na ait açık kaynaklardan elde edilmektedir. Ek olarak, çalışmada kullanılan değişkenlerin seçiminde 2011-2018 yıllarına ait kent bazında veri setine ulaşılabilirlik belirleyici olmakta ve değişkenlerin, düzeyde üstel bir büyüme ve azalış gösteren serilerde ortaya çıkan aşırı değişimin dengelenebilmesi, doğrusal bir formda ifade edilebilmesi ve rassal dağılım gösterebilmesi amacıyla yıllara göre değişim oranları alınarak analiz sürecine dahil edilmektedir. Tablo 1'de değişkenlere ilişkin tanımlanmalar ve tanımlayıcı istatistiklere yer verilmektedir.

Tablo 1. Değişkenlere İlişkin Tanımlayıcı İstatistikler

\begin{tabular}{|c|c|c|c|c|}
\hline VGO & \multicolumn{4}{|c|}{ Verilen Göç Oranı } \\
\hline İHO & \multicolumn{4}{|c|}{ İhracat Oranı } \\
\hline GO & \multicolumn{4}{|c|}{ Girişim Oranı } \\
\hline SGO & \multicolumn{4}{|c|}{ Sosyal Güvenlik Oranı } \\
\hline \multirow[t]{2}{*}{ GOKO } & \multicolumn{4}{|c|}{ Günlük Ortalama Kazanç Oranı } \\
\hline & Ortalama & Standart Sapma & Minimum Değer & Maksimum Değer \\
\hline VGO & 0.019459 & 0.134 & -0.71074 & 0.86620 \\
\hline İHO & 0.197859 & 0.602 & -3.87430 & 7.36184 \\
\hline GO & 0.016453 & 0.021 & -0.17706 & 0.15506 \\
\hline SGO & 0.038071 & 0.027 & -0.01356 & 0.23727 \\
\hline GOKO & 0.114072 & 0.058 & -0.12037 & 0.40312 \\
\hline
\end{tabular}

2018 yılı baz alınarak kentlere ait verilen göç rakamlarına ilişkin oluşturulan mekânsal yoğunluk haritası Şekil 1'de gösterilmektedir. Mavi renkten kırmızı renge doğru artış eğilimi gösteren kentlerin verdikleri göç değerlerine ilişkin mekânsal yoğunluk haritası incelendiğinde, genellikle nüfus yoğunluğu yüksek olan kentlerde (İstanbul, Ankara, İzmir, Bursa vb. gibi) sarı ve kırmızı renk yoğunluğunun yüksek düzeyde olduğu görülmekteyken, 
nüfus yoğunluğu düşük olan, endüstrisi yoğun olmayan ve istihdam seviyeleri yeterli olmayan kentlerde (Kırşehir, Kastamonu, Bayburt, Şırnak, Hakkâri vb. gibi) düşük seviyede eğilim göstermektedir. Bu durum, kentlerdeki göç hareketliliğinin ülke genelinde homojen bir şekilde dağılmadığını göstermektedir.

Şekil 1. Kentlerin Verdikleri Göç Değerlerine İlişkin Mekânsal Yoğunluk Haritası (2018)

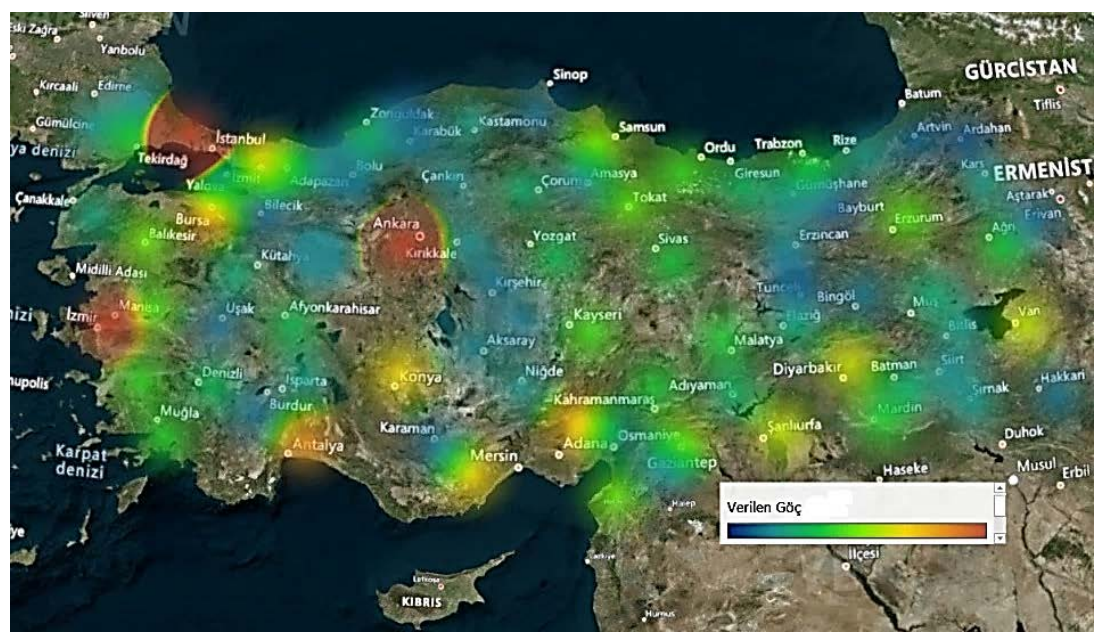

2018 yılı baz alınarak kentlerdeki ihracat rakamlarına ilişkin oluşturulan mekânsal yoğunluk haritası Şekil 2'de gösterilmektedir. Mavi renkten kırmızı renge doğru artış eğilimi gösteren kentlerdeki ihracat rakamlarına ait mekânsal yoğunluk haritası incelendiğinde, genellikle büyük ve endüstrisi yoğun olan kentlerde (İstanbul, Ankara, İzmir, Gaziantep vb. gibi) sarı ve kırmızı renk yoğunluğunun yüksek düzeyde olduğu görülmekteyken, büyük ve endüstrisi yoğun olmayan kentlerde (Çorum, Kastamonu, Tokat, Amasya, Tunceli vb. gibi) düşük seviyede eğilim göstermektedir. Bu durum, kentlerdeki ihracat rakamlarının ülke genelinde homojen bir şekilde dağılmadığını göstermektedir.

Şekil 2. Kentlerdeki İhracat Rakamlarına İlişsin Mekânsal Yoğunluk Haritası (2018)

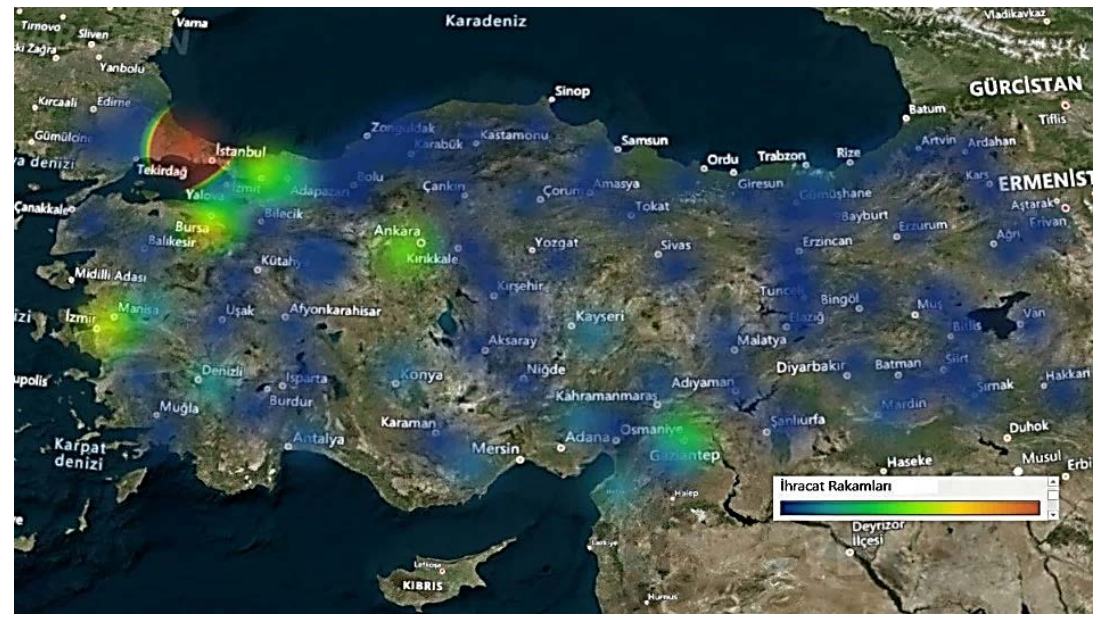


2018 yılı baz alınarak kentlere ait girişim sayılarına ilişkin oluşturulan mekânsal yoğunluk haritası Şekil 3'de gösterilmektedir. Mavi renkten kırmızı renge doğru artış eğilimi gösteren kentlerdeki girişim sayılarına ait mekânsal yoğunluk haritası incelendiğinde, genellikle büyük ve endüstrisi yoğun olan kentlerde (İstanbul, Ankara, İzmir, Adana, Kayseri, Gaziantep vb. gibi) sarı ve kırmızı renk yoğunluğunun yüksek düzeyde olduğu görülmekteyken, diğer kentlerde (Uşak, Yozgat, Çankırı, Bingöl, Siirt vb. gibi) düşük seviyelerde seyretmektedir. Bu durum, kentlerdeki girişim sayıları ülke genelinde homojen bir şekilde dağılım gösteremediğini ifade etmektedir.

Şekil 3. Kentlerdeki Girişim Sayılarına ait Mekânsal Yoğunluk Haritası (2018)

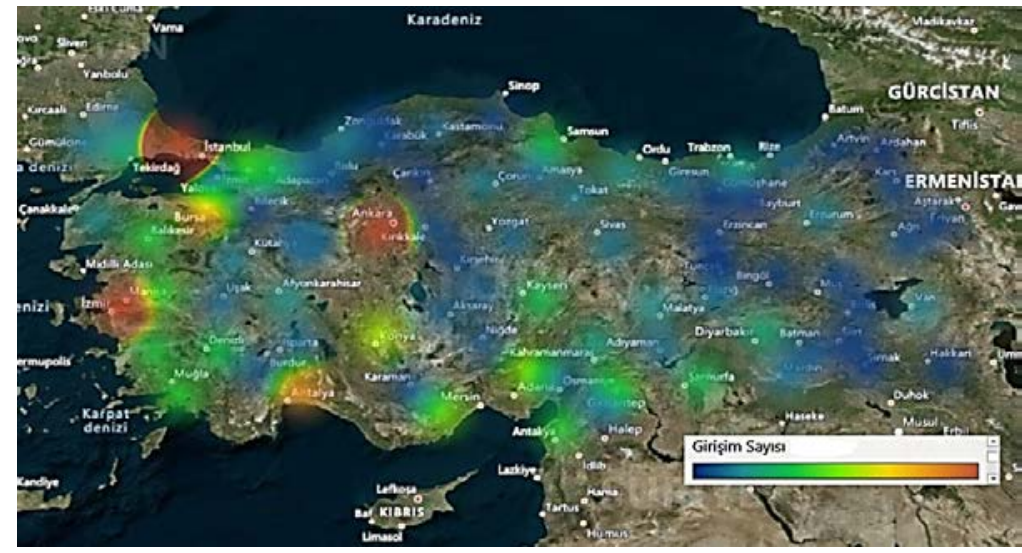

2018 yılı baz alınarak kentlerde bulunan sosyal yardım alan kişi sayısına ele alınarak oluşturulan mekânsal yoğunluk haritası Şekil 4'te gösterilmektedir. Mavi renkten kırmızı renge doğru artış eğilimi gösteren kentlerdeki sosyal yardım alan kişi sayısı ait mekânsal yoğunluk haritası incelendiğinde, nüfus yoğunluğunun yüksek düzeyde kentlerde (İstanbul, Ankara, İzmir, Adana, Kayseri, Bursa, Samsun vb. gibi) sarı ve kırmızı renk yoğunluğunun yüksek düzeyde olduğu görülmekteyken, nispeten daha düşük nüfus yoğunluğuna sahip olan kentlerde (Bilecik, Isparta, Osmaniye, Karabük, Kırşehir) ve ülkenin doğu bloğunda yer alan kentlerde (Bingöl, Muş, Bitlis, Ağrı, Kars vb. gibi) düşük düzeylerde eğilim göstermektedir. $\mathrm{Bu}$ durum, kentlerde sosyal yardım alan kişi sayılarının ülke genelinde homojen bir şekilde dağılım göstermediğini ifade etmektedir.

Şekil 4. Kentlerdeki Sosyal Yardım Alan Kişilere ait Mekânsal Yoğunluk Haritası (2018)

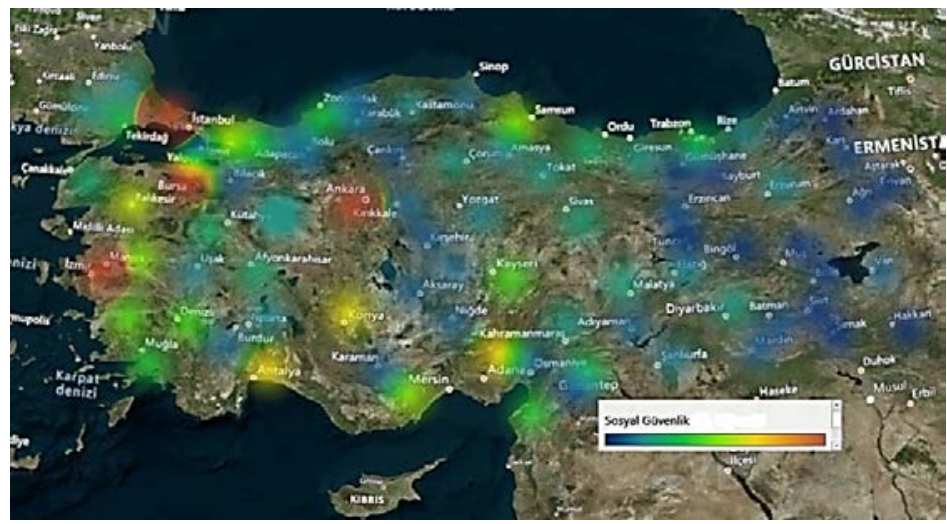


2018 yılı baz alınarak kentlerdeki günlük ortalama kazanç miktarı ele alınarak oluşturulan mekânsal yoğunluk haritası Şekil 5'te gösterilmektedir. Mavi renkten kırmızı renge doğru artış eğilimi gösteren kentlerdeki sosyal yardım alan kişi sayısı ait mekânsal yoğunluk haritası incelendiğinde, büyük ve endüstrisi yoğun olan kentlerde (İstanbul, Ankara, Bursa, Antalya, İzmir, Zonguldak vb. gibi) ve nitelikli işgücünün düşük seviyelerde olan kentlerde (Ağrı, Kars, Artvin vb. gibi) sarı ve kırmızı renk yoğunluğunun yüksek düzeyde olduğu görülmekteyken, nispeten daha düşük işgücüne sahip olan kentlerde (Afyonkarahisar, Niğde, Denizli, Aksaray, Karaman vb. gibi) düşük düzeylerde eğilim göstermektedir. Bu durum, kentlerdeki günlük ortalama kazanç miktarının ülke genelinde küçük farklılıkların olmasına rağmen ortalamadan sapma sergilemesi nedeniyle homojen bir şekilde dağılım göstermediği anlamına gelmektedir.

Şekil 5. Kentlerdeki Günlük Ortalama Kazanç Miktarına ait Mekânsal Yoğunluk Haritası (2018)

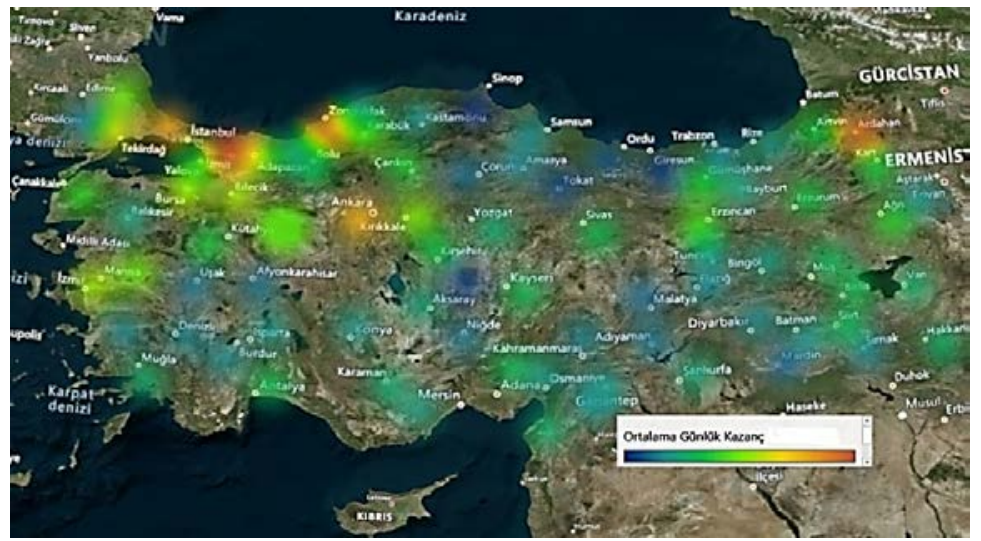

Sonuç olarak, sosyal inovasyon göstergesi olarak elen alınan kentlerdeki sosyal yardım alan kişi sayısına ait mekânsal yoğunluk haritasının (Şekil 4.) ve artımsal inovasyon göstergeleri olarak ele alınan kentlerdeki ihracat rakamlarına, girişim sayılarına ve günlük ortalama kazanç miktarlarına ait (Şekil 2. Şekil 3. ve Şekil 5.) mekânsal yoğunluk haritasının heterojenik bir dağılım sergilemesi kentlerdeki verilen göç oranlarını etkileyen birçok faktör bulunabileceği anlamına gelmektedir.

Mekânsal dağılım haritası incelenen verilerin kentler bazında dağılımını göstermekle birlikte mekânsal ilişkinin anlamlılığı, yönü ve gücü hakkında bilgi sunmamaktadır. Şekil 6'da, kentlerin verdikleri göç değerlerine ilişkin LISA haritası ve Moran-I serpilme diyagramı yer almaktadır. Ek olarak, LISA haritasında yer alan ve beyaz ile işaretlenen alanlar kentler arasında mekândan kaynaklı anlamlı bir korelasyon olmadığı yani kentlerde göç hareketliliği olmasın rağmen mekânsal etkiden kaynaklanmadığını göstermektedir.

Şekil 6. Verilen Gö̧̧ Değerlerine ilişkin LISA haritası ve Moran-I serpilme Diyagramı (2018)
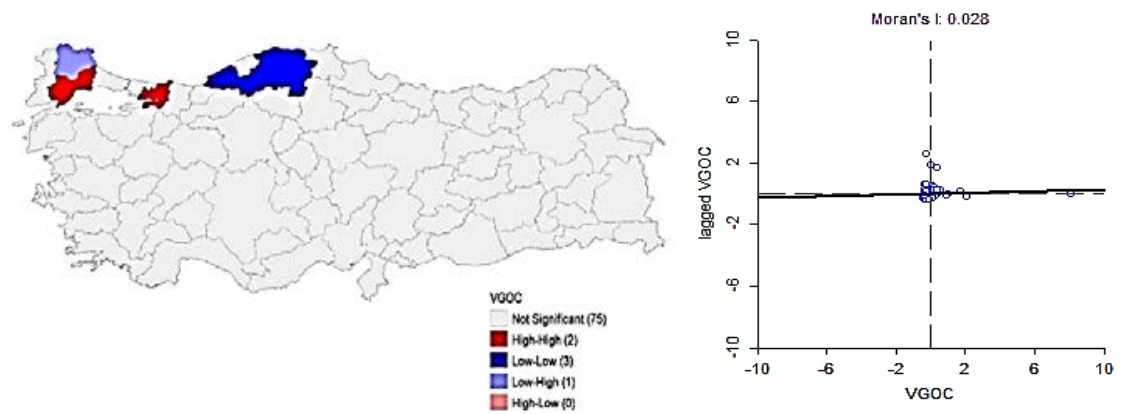
Şekil 6'da bulanan LISA haritasında kırmızı renkle işaretli alanlar, Moran-I serpilme diyagramının I. bölgesinde yer almakta ve ilişkinin derecesinin "yüksek-yüksek" (baz alınan kentte yüksek ise komşusunda da yüksek) olduğu kentleri, pembe renkle işaretli alanlar, Moran-I serpilme diyagramının II. bölgesinde yer almakta ve ilişkinin derecesinin "yüksekdüşük” (baz alınan kentte yüksek ise komşusunda düşük) mavi renkle işaretli alanlar, MoranI serpilme diyagramının III. bölgesinde yer almakta ve ilişkinin derecesinin "düşük-düşük" (baz alınan kentte düşük ise komşusunda da düşük) olduğu kentleri ve lacivert renkle işaretli alanlar, Moran-I serpilme diyagramının IV. bölgesinde yer almakta ve ilişki derecesinin "düşük-yüksek" (baz alınan kentte düşük ise komşusunda yüksek) olduğu kentleri ifade etmektedir. Kentlerin verdikleri göç değerleri için oluşturulan 2018 yılına ait Moran-I serpilme diyagramında bağımlı değişkende pozitif mekânsal otokorelasyonun söz konusu olduğu görülmektedir. Bu nedenle, kentlerin verilen göç değerlerindeki değişimlerin pozitif yönde mekânsal bir yap1 sergilediği söylenebilmektedir. Sosyal inovasyon ve artımsal inovasyon göstergeleri için kullanılan ilgili değişkenlere ait LISA dağılım haritaları Şekil 7'de verilmektedir.

Şekil 7. Sosyal İnovasyon ve Artımsal İnvasyon Göstergelerine İlişkin LISA Haritaları (2018)

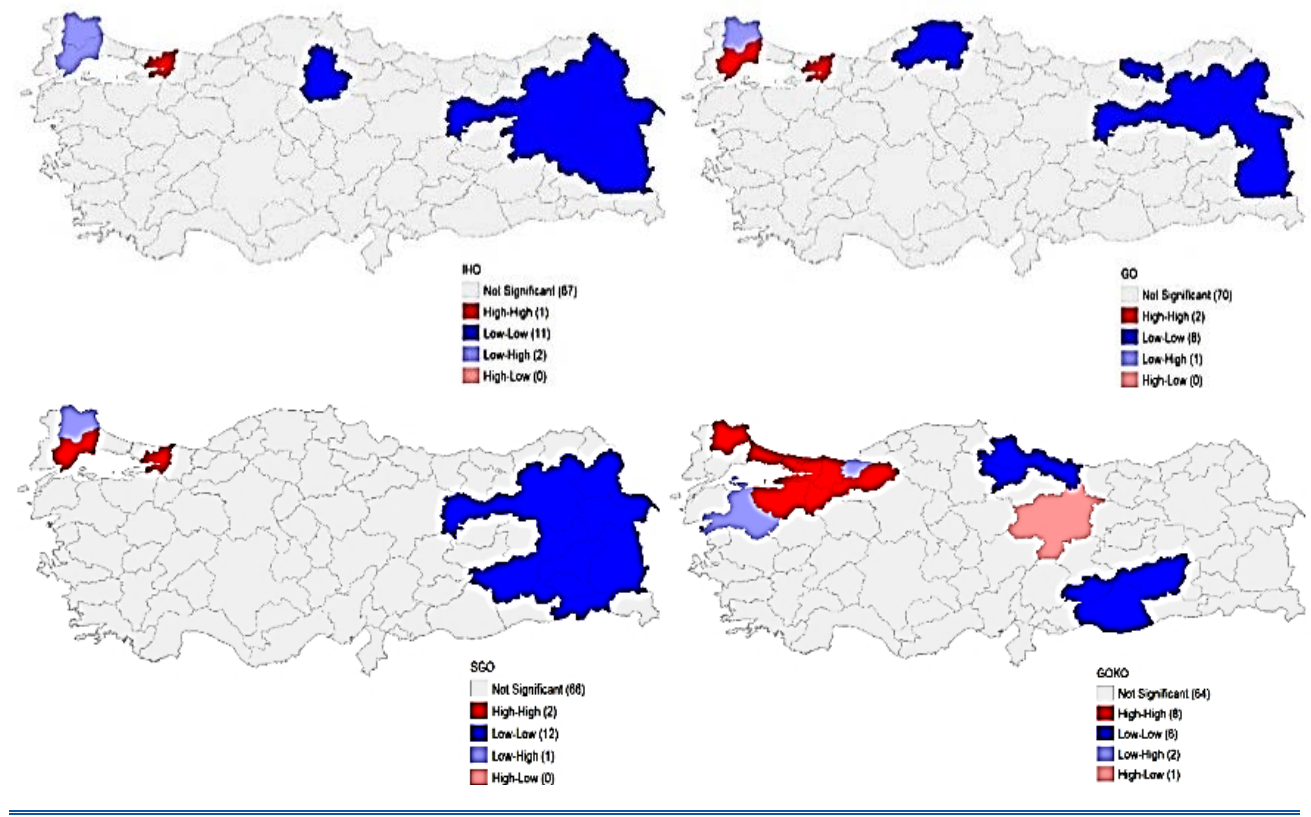

Verilen göç değerlerine ait korelasyonun anlamlı olduğu kentler incelendiğinde, Marmara ve Batı Karadeniz kentlerinde belirgin kümelenme görülmektedir. Sosyal inovasyon ve artımsal inovasyon göstergelerine ilişkin LISA haritaları incelendiğinde, "yükssek-yüksek" ilişkinin olduğunu gösteren kırmızı renk genellikle Marmara kentlerinde yoğunlaşmaktadır. "Düşükdüşük” ilişkinin olduğunu belirten lacivert renk ise genellikle Doğu Anadolu ve Güneydoğu Anadolu kentleri üzerinde kümelenmektedir. Tablo 2'de kentlerdeki verilen göç değerleri, sosyal inovasyon ve artımsal inovasyon göstergelerine ilişkin LISA haritalarında anlamlı olan kentler bulunmaktadır. 
Tablo 2. Sosyal İnovasyon ve Artımsal İnovasyon Göstergelerine İlişkin LISA Haritalarında Anlamlı Olan Kentler

\begin{tabular}{|c|c|c|c|c|}
\hline 2018 & Yüksek-Yüksek & Yüksek-Düşük & Düşük-Düşük & Düșük-Yüksek \\
\hline VGO & Tekirdağ, Kocaeli & & $\begin{array}{l}\text { Karabük, Zonguldak, } \\
\text { Kastamonu }\end{array}$ & Kırklareli \\
\hline їно & Kocaeli & & $\begin{array}{l}\text { Ardahan-Çorum- Kars- } \\
\text { Erzurum-Erzincan-Bingöl- } \\
\text { Muş-Bitlis-Van-Ağr1-Iğdır }\end{array}$ & $\begin{array}{l}\text { Kırklareli- } \\
\text { Tekirdağ }\end{array}$ \\
\hline GO & Kocaeli-Tekirdağ & & $\begin{array}{l}\text { Kastamonu-Trabzon- } \\
\text { Erzincan-Erzurum-Kars- } \\
\text { Ağrr-Van-Karabük }\end{array}$ & Kırklareli \\
\hline SGO & Kocaeli-Tekirdağ & - & $\begin{array}{c}\text { Ardahan-Çorum- Kars- } \\
\text { Erzurum-Erzincan-Bingöl- } \\
\text { Muş-Bitlis-Van-Ağrı-Iğdır- } \\
\text { Diyarbakır } \\
\end{array}$ & Kırklareli \\
\hline GOKO & $\begin{array}{l}\text { Kırklareli-İstanbul- } \\
\text { Kocaeli-Sakarya-Bolu- } \\
\text { Bursa-Yalova-Bilecik }\end{array}$ & Sivas & $\begin{array}{l}\text { Sanliurfa-Adiyaman- } \\
\text { Diyarbakır-Samsun-Amasya- } \\
\text { Ordu }\end{array}$ & Balıkesir-Düzce \\
\hline
\end{tabular}

Makale kapsamında, sosyal inovasyon ve artımsal göstergelerinin iç-göç sorunsalı üzerindeki dinamik mekânsal etkisinin belirlemek üzere kurulan modelde $\rho$ mekansal etkileşim, $i=$ $1, \ldots N$ ve $t=1, \ldots, T$ olmak üzere;

$$
\begin{aligned}
V G O_{i t}= & \beta_{0}+\beta_{1}(V G O)_{i, t-1}+\beta_{2} \Sigma_{j=1}^{N} \rho W_{i j}(V G O)_{j t-1}+\beta_{3} W \dot{\mathrm{I}} H O_{i t}+\beta_{4} W G O_{i t}+ \\
& \beta_{5} W S G O_{i t}+\beta_{6} W G O K O_{i t}+\varepsilon_{i t}
\end{aligned}
$$

şeklinde belirlenmektedir. Eşitlik 4'te, $i$ kentindeki $t$ zamanındaki verilen göç düzeyini $V G O_{i t}$ ve her biri $i \neq j$ olmak üzere kentlerin sınır komşuluk ilişkisi olması durumunda 1 olmaması durumunda 0 olarak ayarlanan standardize edilen ve mekânsal ilişkiyi gösteren mekânsal ağırlık matrisini $W_{i j}$ ifade etmektedir. Herhangi bir kent ile komşuluk ilişkilerin bulunduğu kentlerin arasındaki eşzamanlı mekânsal korelasyonu karakterize eden mekânsal gecikme parametresi $\beta_{2}$ olarak belirtilmektedir. $\beta_{2}=0$ olması durumunda, kentlerin verilen göç düzeylerini ölçmek amacıyla kurulan modelin dinamik mekânsal süreç içermediği ve geleneksel dinamik panel veri yöntemleri ile çözülmesi gerekliğini göstermektedir. $\mathrm{Bu}$ kapsamda, $i$ konumundaki bir kentin $t-1$ anındaki verdiği göç düzeyini $(E K O)_{i, t-1}$ olarak gösterilirken, dönem boyunca verilen göç düzeyinin kalıcı özelliği yansıtılabilmektedir. Mekânsal ilişki sürecini modele dahil edilmesini sağlayan $W_{i j}$, bağımlı değişken ile olan etkileşiminin $t-1$ gecikmesini modele dahil ederek dinamik mekânsal sürecin anlamlılığı test edilebilmektedir. Sosyal inovasyon ve artımsal inovasyonun göç üzerindeki dinamik mekânsal sürecini test amacıyla kurulan modelde, $i$ kentinde $t$ zamanındaki ihracat düzeyini $\mathrm{I} H O_{i t}, i$ kentinde $t$ zamanındaki girişimcilik düzeyini $G O_{i t}$, $i$ kentinde $t$ zamanındaki sosyal güvenlik düzeyini $S G O_{i t}, i$ kentinde $t$ zamanındaki günlük ortalama kazanç düzeyini $G O K O_{i t}$ ve $i$ kentinde $t$ zamanındaki hata terimlerini $\varepsilon_{i t}$ göstermektedir. Tablo 4'te kentler arasındaki verilen göç oranlarını incelemek üzere kurulan modele ilişkin, dinamik yapıda mekânsal bir etkileşimin anlamlılığı araştırılarak, uygun dinamik mekânsal modele karar verilmekte ve sosyal inovasyon ve artımsal inovasyon göstergelerinin göç üzerindeki kısa ve uzun dönem doğrudan ve dolaylı etkileri gösterilmektedir. Ek olarak, açıklayıcı değişkenlerin önünde yer alan $W$ ifadesi değişkenlerin mekânsal ilişkisini belirlemek amaciyla iktisadi modele dahil edilmektedir. 
Tablo 3'te modele ait mekânsal etkileşiminin anlamlılığı, dinamik yapı içerip içermediği ve uygun dinamik mekânsal panel veri modeline karar verilerek, kısa ve uzun dönemdeki doğrudan ve dolaylı etkileri yer almaktadır. Panel yapıya sahip veri setinin mekânsal bağımlılığın anlamlılığı Wald testi ile incelebilmektedir. Kurulan modele ilişkin test sonuçları incelendiğinde, gecikme ve hata değerlerinin \%5 önem düzeyinde reddedildiği gözlemlendiğinden uygun mekânsal panel model SDM (Spatial Durbin Model) model olarak belirlenmektedir.

Tablo 3. Sosyal İnovasyon ve Artımsal İnovasyonun Göç Üzerindeki Kısa ve Uzun Dönem Mekânsal Etkileri

\begin{tabular}{|c|c|c|c|c|c|c|}
\hline & & $V G O_{t-1}$ & SGO & İHO & GO & GOKO \\
\hline & & $\begin{array}{l}-\mathbf{0 . 3 1 1 *} \\
(0.0377) \\
\end{array}$ & $\begin{array}{l}-\mathbf{1 . 3 9 7 4 *} \\
(0.3504) \\
\end{array}$ & $\begin{array}{l}-\mathbf{- 0 . 0 0 8 8} \\
(0.0071)\end{array}$ & $\begin{array}{l}-\mathbf{0 . 6 6 1 9 * *}^{* *} \\
(0.3615) \\
\end{array}$ & $\begin{array}{l}-\mathbf{0 . 5 0 0 1} * \\
(0.1482) \\
\end{array}$ \\
\hline & W.VGO & W.VGO $\boldsymbol{V}_{t-1}$ & W.SGO & W.İHO & W.GO & W.GOKO \\
\hline & $\begin{array}{l}\mathbf{0 . 4 5 7 8}^{*} \\
(0.0514)\end{array}$ & $\begin{array}{l}\mathbf{0 . 2 4 9 *} \\
(0.0567)\end{array}$ & $\begin{array}{l}\mathbf{0 . 1 3 7 8} \\
(0.4983)\end{array}$ & $\begin{array}{l}-\mathbf{- 0 . 0 6 3 3 *} \\
(0.0178)\end{array}$ & $\begin{array}{l}1.3107^{* *} \\
(0.5146) \\
\end{array}$ & $\begin{array}{l}\mathbf{- 0 . 1 6 8 0} \\
(0.1946) \\
\end{array}$ \\
\hline \multicolumn{7}{|c|}{ Kısa Dönem Etki } \\
\hline Doğrudan & & & $\begin{array}{l}-\mathbf{0 . 4 5 4 1 *} \\
(0.3210)\end{array}$ & $\begin{array}{l}-\mathbf{0 . 0 0 7} \\
(0.0080)\end{array}$ & $\begin{array}{l}-\mathbf{0 . 5 4 3 4} * * * \\
(0.3332)\end{array}$ & $\begin{array}{l}-\mathbf{0 . 5 3 9 1 *} \\
(0.1399)\end{array}$ \\
\hline Dolaylı & & & $\begin{array}{l}-\mathbf{- 0 . 8 0 3 4} \\
(0.6911)\end{array}$ & $\begin{array}{l}\mathbf{0 . 1 0 3 5 *} \\
(0.0343)\end{array}$ & $\begin{array}{l}\mathbf{0 . 6 9 3 7}^{* * *} \\
(0.7386)\end{array}$ & $\begin{array}{l}-\mathbf{- 0 . 6 6 9 2 *} \\
(0.2394) \\
\end{array}$ \\
\hline Toplam & & & $\begin{array}{l}-1.2575^{*} \\
(0.6883)\end{array}$ & $\begin{array}{l}\mathbf{0 . 1 0 2 8}^{*} \\
(0.0396)\end{array}$ & $\begin{array}{l}\mathbf{0 . 1 5 0 2 * * *} \\
(0.721)\end{array}$ & $\begin{array}{l}-\mathbf{1 . 2 0 8 4} * \\
(0.2346)\end{array}$ \\
\hline \multicolumn{7}{|c|}{ Uzun Dönem Etki } \\
\hline Doğrudan & & & $\begin{array}{l}-\mathbf{0 . 1 3 4 2 *} \\
(0.2455)\end{array}$ & $\begin{array}{l}\mathbf{0 . 0 0 0 9} \\
(0.0064)\end{array}$ & $\begin{array}{l}-\mathbf{- 0 . 3 9 5 1} \\
(0.2546)\end{array}$ & $\begin{array}{l}-\mathbf{0 . 4 2 5 9 *} \\
(0.1069)\end{array}$ \\
\hline Dolaylı & & & $\begin{array}{l}\mathbf{- 0 . 8 8 8 9} \\
(0.5995)\end{array}$ & $\begin{array}{l}\mathbf{0 . 1 9 1 1}^{*} \\
(0.0307)\end{array}$ & $\begin{array}{l}\mathbf{0 . 4 2 6 2 * *} \\
(0.6398)\end{array}$ & $\begin{array}{l}-\mathbf{- 0 . 6 5 7 1} * \\
(0.2063)\end{array}$ \\
\hline Toplam & & & $\begin{array}{l}-\mathbf{- 1 . 0 2 3 1} \text { * } \\
(0.6149) \\
\end{array}$ & $\begin{array}{l}\mathbf{0 . 1 9 2 1}^{*} \\
(0.0353)\end{array}$ & $\begin{array}{l}\mathbf{0 . 0 3 1 1} * * * \\
(0.6454)\end{array}$ & $\begin{array}{l}\mathbf{- 1 . 0 8 3 1 *} \\
(0.2104)\end{array}$ \\
\hline
\end{tabular}

\begin{tabular}{|c|c|}
\hline Wald Testi $i_{L A G(\lambda)}$ & 26.25* \\
\hline Wald Testi $i_{\text {ERROR }(\rho)}$ & 26.94* \\
\hline $\mathbf{R}^{2}$ & 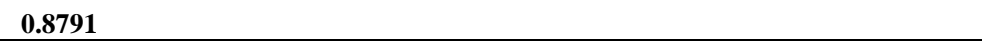 \\
\hline
\end{tabular}

Sosyal inovasyon ve artımsal inovasyon göstergelerinin iç-göç üzerindeki etkisini incelemek için kurulan modele ilişkin mekânsal bağımlılık katsayısının ( $W . V G O)$ pozitif ve istatistiksel olarak anlamlı olması, bağımlı değişkenler ile açıklayıcı değişkenler arasında pozitif mekânsal etkileşimin olduğunun göstergesi olarak kabul edilebilmektedir. Bu durum, bir konumda verilen göç eğilimi ne yönde ise o konumun komşularında da aynı yönde olacağını şeklinde yorumlanabilmektedir. Kurulan model kapsamında, bir önceki döneme ait verilen göç oranını gösteren $V G O_{t-1}$ ifadesinin istatistiksel olarak anlamlı ve negatif çıkması, bir önceki dönemde verilen göç oranının bir sonraki dönemde verilen göç oranı üzerinde negatif etkiye sahip olacağını göstermektedir. Bir önceki döneme ait verilen göç oranının mekânsal etkileşimini gösteren $W V G O_{t-1}$ ifadesinin istatistiksel olarak anlamlı ve pozitif çıkması komşuluk ilişkilerinin bulunduğu kentlerdeki bir önceki dönemde verilen göç oranının, bir sonraki dönemde mevcut kentteki verilen göç oranını değiştirmede pozitif bir etkiye sahip 
olacağını göstermektedir. Bu nedenle, model yapısına ilişkin sürecin dinamik mekânsal bir yapı içerdiği söylenebilmektedir. Dinamik yapıya sahip mekânsal panel veri analizlerinde, hata terimi ve açıklayıcı değişkenler arasında mekânsal otokorelasyonun bulunması, baz alınan konumların bitişik bir yapı sergilemesi ve mekânsal ağırlık matrisinde tanımlanmayan öğelerin bulunmaması nedeniyle tesadüfi etkiler modeli anlamsız sonuçlar vermekte ve bu nedenle sabit etkiler modeli kullanılmaktadır. Tablo 3'te bulunan ana sonuçlar incelendiğinde verilen göçe, girişim oranı, sosyal güvenlik oranı ve günlük ortalama kazanç oranı anlamlı ve ters yönde etkide bulunduğunu ve ihracat oranının istatistiksel olarak anlamsız çıkması nedeniyle herhangi etkide bulunmadığını göstermektedir. Kentler kapsamında verilen göç oranlarına ait kurulan modele mekânsal etkinin dahil edilmesi durumunda ise, kentlerdeki verilen göç oranına ihracat oranı istatistiksel olarak anlamlı ve negatif yönde, girişim oranı istatistiksel olarak anlamlı ve pozitif yönde etkilemektedir.

Statik mekânsal modeller açıklayıcı değişkenlerin yalnızca uzun dönem etkilerini tahmin ederken; dinamik mekânsal modeller kısa dönem etkileri de tahmin sürecine dahil edilmesini sağlamaktadır. Kentler arasında verilen göçü incelemek üzere kurulan modelin dinamik bir yapı sergilediği bilinmektedir. Bu çerçevede herhangi bir kentteki verilen göçün, uzun, kısa ve toplam uzun-kısa döneme ait dolaylı ve doğrudan etkiler incelenmesi gerekmektedir. Dolaylı etkiler, açıklayıcı değişkendeki değişimin, mekânsal etkileşimde bulunan komşu kentlerdeki bağımlı değişken üzerindeki değişimi gösterirken, doğrudan etkiler, aynı kentlerdeki açıklayıcı değişkenlerin bağımlı değişken üzerindeki değişimi ifade etmektedir. Toplam etkiler ise mevcut bir kentteki açıklayıcı değişkenler ile komşuluk ilişkilerinin bulunduğu kent(ler)deki açıklayıcı değişkenlerdeki değişimin mevcut kentteki bağımlı değişkene olan etkisinin yanı sıra dolaylı ve doğrudan (mekânsal) etkilerin toplamını ifade etmektedir. Ek olarak, doğrudan etkiler mekânsal ağırlık matrisinin köşegen elemanlarının ortalaması iken, dolaylı etkiler matrise ait köşegen olmayan ögelerin satır/sütun toplamlarının ortalaması olarak söylenmektedir. Sosyal inovasyon ve artımsal inovasyonun iç-göç üzerindeki uzun ve kısa dönem toplam doğrudan ve dolaylı etkilerine ait sonuçlar Tablo 3 'te gösterilmektedir. Model kapsamında kısa dönemde, girişim oranı, sosyal güvenlik oranı ve günlük ortalama kazanç oranı kentlerin verdikleri göçe istatistiksel olarak anlamlı ve negatif yönde etkide bulunmaktadır. Bu durum, herhangi bir kentteki girişim oranındaki, sosyal güvenlik oranındaki ve günlük ortalama kazanç oranlarındaki artışın, mevcut kentteki verilen göçü ters yönde etkileyebileceği şeklinde yorumlanabilmektedir. Sosyal inovasyon ve artımsal inovasyonun iç-göç üzerindeki mekânsal etkisini incelemek üzere kurulan modele ilişkin kısa dönemde, ihracat oranı ve girişim oranı istatistiki olarak anlamlı ve pozitif, sosyal güvenlik oranı ve günlük ortalama kazanç oranı ise istatistiksel olarak anlamlı ve negatif yönde kentlerin verdikleri göç oranına dolaylı (mekânsal) etkide bulunmaktadır. Bu durum, kısa dönemde herhangi bir kentteki ihracat ve girişim oranındaki artışın komşu kentlerdeki verilen göçe pozitif yönde ve sosyal güvenlik oranı ve günlük ortalama kazanç oranlarındaki değişimin ters yönde bir etkide bulanabileceğini göstermektedir. Kentler arasındaki verilen göç oranlarına kısa dönemde toplam etkiler incelendiğinde kurulan modele ilişkin, doğrudan ve dolaylı etkilerin değerlerinin toplamını göstermekte ve ihracat oranı ve girişim oranı pozitif, sosyal güvenlik oranı ve günlük ortalama kazanç oranı istatistiksel olarak anlamlı ve negatif yönde etkilemektedir. Bu durum, mevcut bir kentteki ve komşuluk ilişkilerinin bulunduğu kent(ler)deki eş zamanlı olarak ihracat oranındaki ve girişim oranındaki artışın verilen göç oranını pozitif yönde, sosyal güvenlik oranındaki ve günlük ortalama kazanç orandaki artışın ters yönde etkileyeceğini ifade etmektedir. Verilen göç oranlarını uzun dönemde, sosyal güvenlik oranı ve günlük ortalama kazanç oranı istatistiksel olarak anlamlı ve negatif bir şekilde doğrudan etkilemektedir. Bu durum, herhangi bir kentteki verilen göçe 
uzun dönemde, sosyal güvenlik oranı ve günlük ortalama kazanç oranındaki değişimin ters yönde etkileyebileceğini göstermektedir.

Sosyal inovasyon ve artımsal inovasyonun iç-göç üzerindeki etkisini incelemek üzere kurulan model, uzun dönemde verilen göçe, ihracat oranı, girișim oranı istatistiksel olarak anlamlı ve pozitif yönde etkide bulunmaktayken, günlük ortalama kazanç oranı istatistiksel olarak anlamlı ve negatif yönde dolaylı (mekânsal) bir etkide bulunmaktadır. Bu durum, uzun dönemde herhangi bir kentteki ihracat ve girişim oranındaki artışın komşu kent(ler)deki verilen göçü pozitif yönde, günlük ortalama kazanç oranındaki artış ters yönde etkileyeceği şeklinde yorumlanabilmektedir. Kentler arasındaki verilen göç oranlarının uzun dönemdeki toplam etkileri incelendiğinde kurulan modele ilişkin, doğrudan ve dolaylı etkilerin değerlerinin toplamını göstermekte ve ihracat oranı ve girişim oranı istatistiksel olarak anlamlı ve pozitif yönde, sosyal güvenlik oranı ve günlük ortalama kazanç oranı istatistiksel olarak anlamlı ters yönde bir etkide bulunmaktadır. Bu durum, mevcut bir kentteki ve komşuluk ilişkilerinin bulunduğu kent(ler)deki eş zamanlı olarak ihracat oranındaki ve girişim oranındaki artışın verilen göç oranını pozitif yönde, sosyal güvenlik oranındaki ve günlük ortalama kazanç orandaki artışın ters yönde etkileyeceğini ifade etmektedir. Sosyal inovasyon ve artımsal inovasyon iç-göç üzerindeki mekânsal etkisini incelemek üzere kurulan modeldeki, kısa dönemdeki değerlerin uzun dönemdeki değerlerden küçük olması modelin makroekonomik açıdan anlamlı olduğu şeklinde yorumlanabilmektedir. Sonuç olarak, dinamik mekânsal bir süreç içeren sosyal inovasyon ve artımsal inovasyon göstergeleri kentlerin verdikleri göçü belirlemede temel yapı taşı olacağı görülmektedir.

\section{SONUÇ}

Ekonomi ve toplum üzerinde önemli etkileri bulunan göç hareketliliği, ülke sınırları içerisinde gelişmiş ve az gelişmiş bölgeler oluşturabilmesi nedeniyle bölgesel kalkınmadaki dengesizliklere sebep olabilmektedir. Yüksek iç-göç devinimine sahip ülkelerde yatırım düzeyinin düşük olması ve işgücüne katılan göçmenlerin artması nedeniyle kentlerde istihdam sorunları artmakta ve bu durum ülke genelinde işsizlik düzeylerini etkilemektedir. Farklı sebeplerden ötürü gerçekleşen iç-göç, nüfus yoğunluğunun, ülke genelinde dengesiz bir yapı sergilemesine neden olarak demografik yapının heterojen dağılımını sağlamaktadır. Kırsal bölgelerde yaşayan insanların büyük kentlere (İstanbul, Ankara, İzmir, Bursa, Adana vb. gibi) göç etmeyi tercih etmesi nedeniyle Türkiye’de iç göç hareketi genellikle ülkenin doğusundan batısına doğru gerçekleşmektedir. $\mathrm{Bu}$ durum, batı kentlerinde bölgesel yatırımların artmasına, girişimcilik açısından cazip hale gelmesine ve kültürel-sosyal erişilebilirliklerin artmasına neden olabilmekteyken, ulusal boyutta sürdürülebilir kalkınmayı sekteye uğratabilmektedir. Türkiye'de coğrafi, ekonomik ve sosyal koşullarda güçlü heterojenliğin bulunması nedeniyle iç-göç, bölgeler arası nüfus dağılımını ve bölgesel dinamikleri etkileyen önemli bir bileşen haline gelmektedir. Ülkelerin ekonomik, sosyal ve siyasal refah seviyesinin artması ve ülkenin uluslararası konjonktürdeki durumunun iyileşmesi mevcut iktidarların uyguladıkları kalkınma politikalarıyla birlikte mümkün olabilmektedir. Ulusal kalkınma için önem kazanan bölgesel kalkınma/gelişmişlik, kalkınma politikalarını etkilemekte ve şekillendirmektedir. Bölgesel kalkınma amacıyla kurulan kalkınma ajanslarında, bölgeler arası dengesizlik nedeniyle yaşanan iç-göç durumunun engellenmesi, bölgeler arasında denge sağlanması, inovasyon ve girişimcilik düzeylerin artırılması, araştırma ve geliştirme faaliyetlerinin/harcamalarının artırılması, küçük ve orta ölçekteki işletmelerin (KOBİ) desteklenmesi yoluyla işsizliğin ve yoksulluğun azaltılarak kişi başı gelirlerin arttırılması, gelir dengesizliği ve fırsat eşitsizliğinin düzeltilmesi, sürdürülebilir bölgesel kalkınma sağlanması ve her bölgenin kendi ihtiyaçları doğrultusunda 
kalkınma stratejisi belirleyerek kalkınması yoluyla çözülmesi hedeflenmektedir. Bu kapsamda, Türkiye'de bölgeler ve kentler arasında kaynakların merkezden dağılımı sonucu ortaya çıkan dengesizlik ve gelişmişlik farkların minimize edilmesi, ülkenin sosyo-ekonomik entegrasyonunun sağlanması, Avrupa Birliği’ne entegrasyon süreci içinde kaynakların daha etkin kullanılması ve yerel yönetimlerin yönetsel ve kaynak gücünün arttırılarak verimliliğin arttırılması amaçlarıyla yeni yaklaşımlar benimsenerek ve merkeziyetçi yapının yanında bölgesel planlamayı da yönetişim süreçlerine dahil edilerek küresel normlara uygun bölgesel kalkınma ajansları kurgulanması veya mevcut kalkınma ajanslarının revize edilmesi gerekmektedir.

Küreselleşme ve modernleşme ile birlikte toplumsal ve bölgesel eşitsizlikler artmaktadır. Toplumdaki potansiyel olarak zayıf kesimlerin (çocuk, yaşlı, hasta, işsiz vb. gibi) temel gıda, sağlık, barınma ve ekonomik gereksinimlerinin karşılanması ve toplumsal refahın oluşturulması amacıyla devletler/hükümetler tarafından gerçekleştirilen eylemler programı olarak tanımlanan sosyal güvenlik politikalarının yeterli düzeyde uygulanmaması göç sorunsalının oluşmasında itici güç olmaktadır. Zayıf kesimlerin temel ihtiyaçlarının karşılanması ve sosyal güvence altına alınması bireylerde dışlanmışlık ve geri kalmışlık psikolojisinin azalmasına ve geleceğe daha umutla bakmasına neden olmaktadır. Çalışma kapsamında kentlerdeki sosyal inovasyon düzeyi, verilen göç üzerinde kısa ve uzun dönemde de hem doğrudan hem de dolaylı (mekânsal) açıdan negatif etkisinin olduğu belirlenmektedir. Örnek vermek gerekirse; Elâzı̆̆ kentindeki sosyal inovasyon faaliyetlerinde artış yaşanması durumunda bireysel/kitlesel göç hareketliliği yaşanmamakta ve Elâzı ̆g kentinin komşuluk ilişkilerinin bulunduğu Malatya kentinde sosyal inovasyon faaliyetlerinde artış yaşansa bile bireyler/kitleler bulundukları kentte yaşamaya devam edebilmektedir. Bu durum, sosyal inovasyon uygulamalarının yüksek düzeyde ve yerinde yapıldığını ve bireylerin kentlerdeki sosyal inovasyon düzeyinin artması durumunda geçimlerini ve sağlık durumunu sağlayabilmesi nedeniyle bulundukları yerden ayrılmadığını göstermektedir. $\mathrm{Bu}$ nedenle, göç olgusundaki düzensiz hareketliğinin azaltılabilmesi için sosyal inovasyon kavramına daha fazla önem verilmesi gerekmektedir.

Reel milli gelirinin devamlı ve kümülatif olarak artışını sağlayan, sosyal, kültürel ve politik değişkenlerin bileşimi olarak tanımlanan kalkınmanın amaçları arasında toplumsal refahın artırılması da yer almaktadır. Bireylere yapılan yatırımları diğer bir ifadeyle imkân/fırsat eşitliği sunulumu ve eğitim, sağlık, sosyal güvenlik, teknoloji yatırımlar, gelir vb. gibi yaşam standartlarının iyileşmesini beraberinde getiren kalkınma, dengeli ve sürdürülebilir bir büyüme sürecine yardımcı olabilmekteyken, dengesiz göç üzerinde de azaltıcı etkiye sebep olabilmektedir. Gelişmekte olan ülkelerin sürdürülebilir kalkınma hedeflerine ulaşma noktasında önemli bir noktada bulanan inovasyon faaliyetleriyle birlikte rekabet edebilme üstünlüğünün sağlanması, üretimde verimliliğin artması ve bölge/ülke genelinde gelişmişlik düzeylerini artırabilmektedir. İnovasyon faaliyetlerinin kalkınmayla doğru orantılı ilerlemesi ülkelerin gelişmelerinde katkıda bulanabilmektedir. Çalışma kapsamında elde edilen bulgular, girişim oranındaki değişimin kentler arası verilen göç üzerinde kısa/uzun dönemde negatif yönde doğrudan etkide bulunduğunu ve pozitif yönde dolaylı (mekânsal) etkide bulunduğunu göstermektedir. Örnek vermek gerekirse; İstanbul kentindeki inovasyon faaliyetlerinde artış yaşanması durumunda göç hareketliliği yaşanmamakta, İstanbul kentinin komşuluk ilişkilerinin bulunduğu Tekirdağ kentinde inovasyon faaliyetlerinin artması sonucu İstanbul kentinden Tekirdağ kentine doğru göç hareketliği yaşanabilmektedir. Bu durum, kentlerdeki verilen göç oranında dengenin sağlanması için inovasyon faaliyetlerinin önemli olduğunu göstermektedir. Sonuç olarak, kentsel/bölgesel olarak inovasyon faaliyetlerinin artırabilmesi için büyüyen ekonominin temelini oluşturması araştırma- 
geliştirme faaliyetlerinin geliştirilmesi, sanayi, araştırma kuruluşları, üniversiteler ve araştırmacıların işbirliği ve eşgüdümlerini sağlayacak önlemler getiren faaliyet alanlarının artımsal, etkin ve dinamik bir şekilde planlanması-uygulanması gerekmektedir.

Tüketim politikalarının endeksli olduğu bölgelerde yaşayan bireyler zamanla geçim kaygılarından ötürü ihracatın yoğun olduğu bölgelere göç etme arzusu taşıyabilmesi, kentler/bölgeler arası verilen göç hareketliliğini artabilmektedir. Göç sorunsalının temel belirleyicileri arasında göç edilen bölgedeki göç maliyetlerinin gelirden daha yüksek olması ve sermayesi düşük, işgücü arzı yüksek olan göç veren bölgelerle sermayesi yüksek ancak endüstrilerini geliştirebilecek işgücüne ihtiyaç duyan göç alan bölgeler arasındaki yapısal ayrımların bulunması nedeniyle kazanılan ücret farklılıkları yer almaktadır. Fayda ve maliyet yaklaşımı, bireylerin göç etme kararlarının fayda-maliyet eksenlerine bağlı olduğunu vurgulamaktadır. Bu nedenle, kazanılan ücretlerde optimum noktaya ulaşılana kadar göç artışı sürmekte ve bireyler/kitleler düşük ücretli ekonomilerden yüksek ücretli olanlara göç etmektedir (King, 2012). Gelir dağılımın adil olmaması diğer bölgelere göç hareketliliğine neden olabilmekteyken, gelir dağılımı eşitsizliğinin arttığı bölgelerde ekonomik büyüme yavaşlamakta ve toplumsal refah sekteye uğramaktadır. Bireysel/toplumsal temel ihtiyaçların karşılanma seviyesindeki artış yaşanması ve gelir dağılımını optimal seviyeye çıkması, büyümeyi ve kalkınmayı olumlu yönde etkileyerek göç hareketliliğinde azalma yaşanmasına neden olmaktadır. Çalışma kapsamında, kentlerdeki makroekonomik gelişmelerin verilen göç üzerinde kısa ve uzun dönemde de negatif yönde doğrudan ve dolaylı bir etkisinin bulunduğu belirlenmektedir. Örnek vermek gerekirse; Eskişehir kentinde yaşayan bireyler, makroekonomik iyileştirmelerde artış yaşanması durumunda göç hareketliliği yaşanmamakta ve Eskişehir kentinin komşuluk ilişkilerinin bulunduğu Ankara kentinde bireysel makroekonomik iyileştirmelerde artış yaşansa bile bulundukları kentte yaşamaya devam edebilmektedir. Bu durum, göç etmeye karar veren bireylerin/kitlelerin, yüksek gelirli bölgelerin genellikle sermaye yoğun olması, geçim şartlarının yüksek olması, çevresel, gürültü vb. gibi kirliliklerin yoğun bir şekilde bulunması ve güvenlik sorunlarının bulunması nedeniyle göç hareketliliğinden vazgeçebileceğini ve bulundukları bölgede yaşamlarını sürdürebileceğini göstermektedir. Bu nedenle, düzensiz göç hareketliliğinin azaltılabilmesi için bireysel gelir dağılımında adaletin sağlanması gerekmektedir.

Dış ticaret akışı, ülkelerin iktisadi kalkınma açısından tamamlayıcı unsurları arasında yer almaktadır. Küreselleşmenin artmasıyla birlikte teknolojik erişilebilirliğin gelişmesi sonucu iletişim ve ulaşım sektörlerinde maliyetlerin azalması, ülkeler/bölgeler arasındaki fiziki sınırların fonksiyonunu değiştirmesine ve ülkeler açısından dış ticaret akışının önem düzeyinde artış yaşanmasına neden olmaktadır. Bu kapsamda ülke ekonomilerinin, uluslararası konjonktürde rekabet edilebilirlikte başarıya ulaşabilmeleri için çağın gerekliliklerine uygun mal ve hizmet üretmeleri gerekmektedir. Çalışma kapsamında elde edilen bulgular, kısa dönemde kentlerdeki ihracat rakamlarının verilen göç üzerinde negatif yönde doğrudan etkide ve dönem fark etmeksizin pozitif yönde dolaylı (mekânsal) etkide bulunduğunu göstermektedir. Örneğin vermek gerekirse; bireyler, İzmir kentindeki ihracat rakamlarında artış yaşanması durumunda göç hareketliliğinden vazgeçebilmekteyken, İzmir kentinin komşuluk ilişkilerinin bulunduğu Manisa kentinde ihracat rakamlarında artış yaşanması sonucu İzmir kentinden Manisa kentine doğru göç kararı alabilmektedir. Bu durum, kente ilişkin ihracat rakamları arttığı için bireylerde kentsel gelir artışı oluşması nedeniyle göç hareketliliğinin gerçekleşmeyeceğine göç akışının bulunduğu kentlerde/bölgelerde göçmenlerle ticaret arasında tamamlayıcılık ilişkisinin oluşabileceğine ve göç akışının bulunduğu bölgelerdeki bireysel işgücü tecrübelerinin gelişmesi nedeniyle bölgesel/kentsel ihracat kapasitesinde artış yaşanabileceğine işaret etmektedir. Bununla 
birlikte hem ihracat rakamlarındaki artış hem de lojistik (taşıma maliyeti) anlamında sağlanan kolaylıklar göz önüne alındığında ihracat yoğunluğu olan kentlere/bölgelere doğru göç akışı oluşmaktadır. Özetle, kentlere özgü ihracatı yapılacak mal ve hizmetlerin belirlenmesi ve desteklenmesi kapsamında politika süreçlerinin tasarlanmasının yanı sıra lojistik süreçlerinin de kurgulanması göç hareketliliği üzerinde etkili olabileceği beklenmektedir.

Ülkelerin, ulusal araştırma ve geliştirme sistemlerini genişletebilecek, piyasalarını uluslararası piyasa ile bütünleştirebilecek, girişimcilik seviyesini yükseltebilecek, göç alanveren bölgeler arasındaki etkileşimle birlikte ulusal iş bölümünü iyileştirecek ve bölgesel işgücü arzı kıtlıklarının aşılmasını (teknolojik gelişme ve sanayileşmede iyileşme) sağlayabilecek olan yüksek nitelikli işgücü, verimli ve düzenli göç hareketliliği sonucunda sağlanabilmektedir. Sonuç olarak, kentsel idari kurumlarının, bölgesel kalkınma ajanslarının ve politika yapıcılarının, sürdürülebilir kalkınma normlarına uygun bir şekilde sosyal inovasyon ve başta artımsal olmak üzere inovasyon, girişimcilik ve araştırma-geliştirme politikalarını gözden geçirmesi ve komşuluk ilişkilerini esas alarak her kentin dinamiklerine (coğrafi yapısı, kültürel yapısı vb. gibi) uygun bir şekilde yapısal reformların düzenlemesi ve uygulanması gerekmektedir.

\section{Kaynakça}

Ahuja, G. ve Katila, R. (2001). Technological Acquisitions and the Innovation Performance of Acquiring Firms: A Longitudinal Study. Strategic Management Journal. 22.3.197-220.

Anselin, L. (1988). Spatial Econometrics: Methods and Models. Kluwer Academic Publishers.

Anselin, L. ve Bera, A. (1988). Spatial Dependence in Linear Regression Models With an Introduction to Spatial Econometrics. (Derleyenler: Ullah, A., Giles, D. E.). Handbook of Applied Economic Statistics. 237. 289. Marcel Dekker. New York.

Anselin, L., Le Gallo, J. ve Jayet, H., (2008). Spatial Panel Econometrics. Springer, Berlin, Heidelberg.

Aralica, Z., Račić, D. ve Radić, D. (2008). Innovation Propensity in Croatian Enterprises: Results of the Community Innovation Survey. South East European Journal of Economics and Business. 3.1.77-88.

Bolukçu, F. (2020). Türkiye'nin Sosyal Güvenlik Harcamalarının Kapsamı ve Finansman1. Türkiye Sağllk Bilimleri ve Araştırmaları Dergisi. 2. 2. 11-27.

Brennan, E. (2010). Definitions For Social Sustainability and Social Work Paper. In White Paper Distributed For CSWE Conference. Portland State University.
Bülbül, S. ve Köse, A., (2010). Türkiye’de Bölgelerarası İç Göç Hareketlerinin Çok Boyutlu Ölçekleme Yöntemi ile İncelenmesi. İstanbul Üniversitesi İsletme Fakültesi Dergisi. 39.1.

Calabrese, G. Coccia, M. ve Rolfo, S. (2005). Strategy and Market Management of New Product Development and Incremental Innovation: Evidence From Italian SMES.” International Journal of Product Development. 2.1. 170.189 .

Ceritli, İ. Sunar, B. ve Demirci, M. (2005). Ülkemizin İ̧̧ Gö̧ Yapısındaki Değişim ve Bu Sürecin Nüfus Yapisina Etkileri. 14. İstatistik Araştırma Sempozyumu.

Çatalbaş, G. K., ve Yarar, Ö., (2015). Türkiye'deki Bölgeler Arası İç Göçü Etkileyen Faktörlerin Panel Veri Analizi ile Belirlenmesi. Alphanumeric Journal.

Çoban, C. (2013). Different Periods of Internal Migration in Turkey From the Perspective of Development. American International Journal of Contemporary Research. 3.10.

Darmofal, D. (2006). Spatial Econometrics and Political Science. In Annual Meeting of Southern Political Science Association. Atlanta. GA. 5.7.

Demirkaya, H. ve Artvinli, E. (2011). Migration Towards Tarsus Antalya and Fethiye: Reasons and Results. Procedia-Social and Behavioral Sciences. 19. 297.307. 
Sosyal İnovasyon ve Artımsal İnovasyon Çerçevesinde İç-Göç Olgusunun Dinamik Mekânsal Etkileşimi

Demirkıran, S., Yücel, M. A. ve Terzioğlu, K. M. (2020). Dijitalleşmenin Düzenleyici Kalite Üzerindeki Etkisi. SADAB 7th International Conference on Social Researches and Behavioral Sciences. (Ekim 2020). Antalya. Türkiye

Doğan, G. U. ve Kabadayı, A. (2015). Determinants of Internal Migration in Turkey: A Panel Data Analysis Approach. Border Crossing. 5.1.2. 16-24.

Döm, S. (2008). Girişimcilik ve Küçük İşletme Yöneticiliği. Detay Yayıncılık.

Elhorst, J. P. (2012). Dynamic Spatial Panels: Models, Methods and Inferences. Journal of Geographical Systems. 14.1. 5-28.

Ersungur, Ş. M. ve Doru, Ö. (2014). Türkiye'de Dış Ticaret ve Ekonomik Kalkınma İlişkisinin Ekonometrik Analizi: 1980-2010. Ataturk University Journal of Economics \& Administrative Sciences. 28.3.

European Commission (2013). Guide to Social Innovation-Regional and Urban Policy. [http://ec.europa.eu/regional_policy/sources/do cgener/presenta/social_innovation/social_innov ation_2013.pdf.]. [Erişim: 14 Ocak 2021]

Filiz, Z. ve Çemrek, F. (2005). Avrupa Birliğine Üye Ülkeler ile Türkiye'nin Karşılaştırılması. İstanbul Üniversitesi VII. Ulusal Ekonometri ve Ístatistik Sempozyumu İstanbul/Türkiye.

Filiztekin, A. (2008). Türkiye'de Bölgesel Farklar ve Politikalar. TÜSIAAD Raporu. [https://tusiad.org/tr/yayinlar/raporlar/item/423 7-turkiyede-bolgesel-farklar-ve-politikalar]. [Erişim: 14 Ocak 2021]

Fischer, M. M. ve Wang, J. (2011). Spatial data Analysis: Models. Methods and Techniques. Springer Science \& Business Media.

Getis, A. ve Aldstadt, J. (2004). Constructing the Spatial Weights Matrix Using a Local Statistic. Geographical Analysis. 36.2. 90-104.

Gezici, F. ve Keskin, B. (2005). Interaction Between Regional Inequalities and Internal Migration in Turkey. In 45th Congress of the European Regional Science Association: Land Use and Water Management in a Sustainable Network Society. Amsterdam/Netherlands
Gökhan, A. (2008). The Determinants of Internal Migration in Turkey. Master Thesis. Sabanc1 University Graduate School of Social Sciences. İstanbul

Holmberg, J. ve Sandbrook, R. (1992). Sustainable Development: What is to Be Done? Policies for a Small Planet. 19.38.

Jansen, J. J. Van Den Bosch, F. A. ve Volberda, H. W. (2006). Exploratory Innovation, Exploitative Innovation and Performance: Effects of Organizational Antecedents and Environmental Moderators. Management Science. 52.11. 1661-1674.

Karabulut, K. ve Polat, D. (2007). Ağrı Alt Bölgesi'ndeki Göç Eğilimi ve Sosyo-Ekonomik Nedenleri. Bilimsel Araştırma Projesi. Atatürk Üniversitesi. Erzurum.

Karbowski, A. ve Prokop, J. (2020). The Impact of Patents and R\&D Cooperation on R\&D Investments in a Differentiated Goods Industry. The South East European Journal of Economics and Business. 15.1.122-133.

Lachenmaier, S. ve Woessmann, L. (2006). Does Innovation Cause Exports? Evidence from Exogenous Innovation Impulses and Obstacles Using German Micro Data. Oxford Economic Papers. 58.2. 317-350.

Le Gallo, J. (2002). Econométrie Spatiale: L'autocorrélation Spatiale Dans Les Modèles de Régression Linéaire. Economie Prevision. 4. 139-157.

LeSage, J. P. (1999). The Theory and Practice of Spatial Econometrics. University of Toledo. Toledo, Ohio. 28.11.

Lucas, R. E. (2015). Internal Migration in Developing Economies: An Overview. KNOMAD’s Working Paper. 6.

Monferrer, D., Blesa, A. ve Ripolles, M. (2012). Competitiveness Through Strategic Orientation. Market- Tržište. 24.2. 165-168.

Mota, R., ve Scott, D. (2014). Education For Innovation and Independent Learning. Elsevier.

Mulgan, G. (2006). The Process of Social Innovation. Innovations: Technology, Governance, Globalization. 1.2. 145-162.

Nakhoul, T. E. (2014). Uluslararası İşgücü Göçü ve Türkiye. Uzmanlık Tezi. T.C. Çalışma ve Sosyal Güvenlik Bakanlığı, Ankara. 
Oosterlynck, S., Kazepov, Y., Novy, A., Cools, P., Barberis, E., Wukovitsch, F. ve Leubolt, B. (2013). The Butterfly and the Elephant: Local Social Innovation. The Welfare State and New Poverty Dynamics. ImPRovE Methodological Paper. 13.02.

Özmucur, S. ve Silber, J. (2002). Spatial Inequality in Turkey and the Impact of Internal Migration. Cornell/LSE/Wider Conference on Spatial Inequality and Development. London. The United Kingdom.

Pech, R. J. ve Cameron, A. (2006). An Entrepreneurial Decision Process Model Describing Opportunity Recognition. European Journal of Innovation Management.

Parrado, E. A. ve Cerrutti, M. (2003). Labor Migration Between Developing Countries: The Case of Paraguay and Argentina. International Migration Review. 37.1. 101-132.

Pazarlıŏlu, M. V. (2007). İzmir Örneğinde İç Göçün Ekonometrik Analizi. Yönetim ve Ekonomi: Celal Bayar Üniversitesi İktisadi ve İdari Bilimler Fakültesi Dergisi. 14.1. 121-135.

Porter, M. E. (1990). The Competitive Advantage of Nations. Free Press. New York.

Radas, S., ve Božić, L. (2009). The Antecedents of SME Innovativeness in an Emerging Transition Economy. Technovation. 29.6-7. 438-450.

Rae, M. (2006). Health Inequalities A Sustainable Development issue. Public Health. 12.120. 1106-1109.

Rogers, E. M. (2003). Diffusion of Innovations. Free Pres: New York

Sarja, J. (2015). Explanatory Definitions of the Technology Push Success Factors. Journal of Technology Management \& Innovation. 10.1. 204-214.

Sigeze, C. ve Balli, E. (2006). The Determınants of Internal Migration: The Case of Turkey. International. Journal of Economics and Finance Studies. 8(2).

Talke, K. (2007). Corporate Mindset of Innovating Firms: Influences on New Product Performance. Journal of Engineering and Technology Management. 24.1-2. 76-91.

Tanfer, K. (1983). Internal Migration in Turkey: Socioeconomic Characteristics by Destination and Type of Move. 1965-70. Studies in Comparative International Development. 18.4. 76-111.
Terzioğlu, M. K., Bulut, M. ve Erkut, E. N. (2018). Göç: Girişimcilik ve Bilgi Teknolojilerinin Etkisi. ICOAEF'18 IV. International Conference on Applied Economics and Finance \& Extended With Social Sciences (Kasim 2018).

Terzioğlu, M. K., Sert, S., Aygün, M. (2018) Göç ve Beşerî Sermaye: Doğu Avrupa Ülkeleri. ICOAEF'18 IV. International Conference on Applied Economics and Finance \& Extended with Social Science (Kasım 2018)

Terzioğlu, M. K., Yücel, M. A., Demirkıran S. ve Acaroğlu, D. (2020). Kentsel İnovasyonun Kentleşme Üzerine Mekânsal Etkisi. IDEALKENT. $\quad 11.30 . \quad$ 592-620. DOI:10.31198/idealkent.683583

Terzioğlu, M. K. ve Yaşar, A. (2018). Göç: Kentleşme ve Suçun Sosyal Maliyeti. IX. Uluslararast STK Kongresi Sunumlart. 15-17 Kasım 2018. Çanakkale. Türkiye

Terzioğlu, M. K., Aygün, G. ve Kandemir, H. (2018). Yoksulluk ve Sosyal Transferler Kapsamında Göç Dinamikleri. IX. Uluslararası STK Kongresi Sunumları. 15-17 Kasım 2018. Çanakkale. Türkiye

Terziovski, M. (2010). Innovation Practice and its Performance Implications in Small and Medium Enterprises (SMEs) in the Manufacturing Sector: Aresource-Based View. Strategic Management Journal. 31.8. 892-902.

Tushman, M. L. ve Anderson, P. (1986). Technological Discontinuities and Organizational Environments. Administrative Science Quarterly. 439-465.

Tutar, H., ve Özyakışır, D. (2013). Trakya Bölgesinden İstanbul'a Göç Hareketlerinin Nedenlerine İlişkin Bir Araştırma. Sosyoloji Konferanslart. 47. 31-58.

\section{TÜIK (2018). Kazanç Yapısı Araştırması.}

$\mathrm{Xu}$, S. (2015). Balancing the Two Knowledge Dimensions in Innovation Efforts: An Empirical Examination Among Pharmaceutical Firms. Journal of Product Innovation Management. 32. 4. 610-621.

Yamak, N. ve Yamak, R. (1999). Türkiye'de Gelir Dağılımı ve İç Göç. Dokuz Eylül Üniversitesi Sosyal Bilimler Dergisi. 1. 1. 
Yücel, M. A. (2021). Çevresel Sürdürülebilirliğin Değerlendirilmesi: Dinamik Mekânsal Panel Veri Yaklaşımı. Bilgi Sosyal Bilimler Dergisi. 23.1. 53-90

Yücel, M. A. (2021). Sürdürebilir Kalkınma Kapsaminda Eko-Verimlilik ve Eko-Inovasyon: Dinamik Mekansal Panel Veri Analizi. (Yüksek Lisans Tezi). Trakya Üniversitesi Sosyal Bilimler Enstitüsü Ekonometri Anabilim Dalı.

Yüksel, S., Eroğlu, S. ve Özsarı, M. (2016). An Analysis of the Reasons of Internal Migration in Turkey With Logit Method. Business and Management Horizons. 4.2. 34-45.

Zeren, F. ve Yarasir, S. T., (2013). An Analysis of Internal Migrations on the Basis of Provinces in Turkey With the Performance Indicators: A Spatial Probit Model. Journal of Applied Economic Sciences Quarterly. 8.3. 286-298. 
